Article

\title{
Assessment of an Automated Calibration of the SEBAL Algorithm to Estimate Dry-Season Surface-Energy Partitioning in a Forest-Savanna Transition in Brazil
}

\author{
Leonardo Laipelt ${ }^{1, *}$, Anderson Luis Ruhoff ${ }^{1,2}{ }^{\oplus}$, Ayan Santos Fleischmann ${ }^{1}$, \\ Rafael Henrique Bloedow Kayser ${ }^{1}$, Elisa de Mello Kich ${ }^{1}$, Humberto Ribeiro da Rocha ${ }^{3}$ and \\ Christopher Michael Usher Neale ${ }^{2}$ \\ 1 Institute of Hydraulic Research, Federal University of Rio Grande do Sul, Porto Alegre 91501-970, Brazil; \\ anderson.ruhoff@ufrgs.br (A.L.R.); ayan.fleischmann@ufrgs.br (A.S.F.); rafael.kayser@ufrgs.br (R.H.B.K.); \\ elisa.kich@ufrgs.br (E.d.M.K.) \\ 2 Daugherty Water for Food Global Institute, University of Nebraska, Lincoln, NE 68588, USA; \\ cneale@nebraska.edu \\ 3 Institute of Atmospheric Sciences, University of Sao Paulo, Sao Paulo 05508-090, Brazil; \\ humberto.rocha@iag.usp.br \\ * Correspondence: leonardo.laipelt@ufrgs.br; Tel.: +55-51-3308-6415
}

Received: 20 February 2020; Accepted: 27 March 2020; Published: 31 March 2020

\begin{abstract}
Evapotranspiration (ET) provides a strong connection between surface energy and hydrological cycles. Advancements in remote sensing techniques have increased our understanding of energy and terrestrial water balances as well as the interaction between surface and atmosphere over large areas. In this study, we computed surface energy fluxes using the Surface Energy Balance Algorithm for Land (SEBAL) algorithm and a simplified adaptation of the CIMEC (Calibration using Inverse Modeling at Extreme Conditions) process for automated endmember selection. Our main purpose was to assess and compare the accuracy of the automated calibration of the SEBAL algorithm using two different sources of meteorological input data (ground measurements from an eddy covariance flux tower and reanalysis data from Modern-Era Reanalysis for Research and Applications version 2 (MERRA-2)) to estimate the dry season partitioning of surface energy and water fluxes in a transitional area between tropical rainforest and savanna. The area is located in Brazil and is subject to deforestation and cropland expansion. The SEBAL estimates were validated using eddy covariance measurements (2004 to 2006) from the Large-Scale Biosphere-Atmosphere Experiment in the Amazon (LBA) at the Bananal Javaés (JAV) site. Results indicated a high accuracy for daily ET, using both ground measurements and MERRA-2 reanalysis, suggesting a low sensitivity to meteorological inputs. For daily ET estimates, we found a root mean square error (RMSE) of $0.35 \mathrm{~mm}^{\text {day }}{ }^{-1}$ for both observed and reanalysis meteorology using accurate quantiles for endmembers selection, yielding an error lower than 9\% (RMSE compared to the average daily ET). Overall, the ET rates in forest areas were $4.2 \mathrm{~mm} \mathrm{day}^{-1}$, while in grassland/pasture and agricultural areas we found average rates between 2.0 and $3.2 \mathrm{~mm} \mathrm{day}^{-1}$, with significant changes in energy partitioning according to land cover. Thus, results are promising for the use of reanalysis data to estimate regional scale patterns of sensible heat $(H)$ and latent heat $(L E)$ fluxes, especially in areas subject to deforestation.
\end{abstract}

Keywords: Amazon; Cerrado; deforestation; evapotranspiration; SEBAL 


\section{Introduction}

Evapotranspiration $(E T)$, defined as the sum of evaporation and vegetation transpiration leaving the surface and entering the atmosphere as water vapor, is a key process in the terrestrial water, carbon, and energy cycles [1]. In the current scenarios of land cover changes associated with deforestation and increasing agricultural areas in the tropics, monitoring surface energy fluxes and ET over large areas is a fundamental requirement to assess changes in the water cycle. For instance, climate change associated with deforestation could impact the water cycle due to alterations in ET rates [2-5], atmospheric water vapor content, and precipitation rates [6,7], ultimately modifying the hydrological surface-atmospheric feedback [8]. In the Amazon and the Cerrado (Brazilian savanna) biomes, conversion from natural vegetation to cropland, concurrent to the expanding Brazilian agricultural frontier [9], has led to significant changes in surface energy balance, with decreases in latent heat $(L E)$, increases in sensible heat $(H)$ and changes in river discharges $[4,10-13]$. Since tropical rainforests play a fundamental role in initiating the dry-to-wet season transition, land cover changes can potentially disrupt the wet season in tropical biomes [14] and contribute to making the dry season longer, with potentially severe ecological consequences [15].

Assessing the effects of large-scale surface-atmospheric interactions and hydrological changes may be accomplished with remote sensing techniques using multispectral and thermal images to calculate the energy balance [16-18]. Remote sensing-based ET models can add to information from the small footprint of eddy covariance [19], since those measurements do not provide spatial trends at a large scale or for heterogeneous surfaces [16]. To estimate the spatial and temporal patterns of $E T$, many types of models are currently in use, from regional to continental and global scales, grouped into two general classes: (i) vegetation index-based and (ii) land surface temperature $\left(T_{s}\right)$ methods $[17,20]$. The first group, including the Global Land-surface Evaporation Amsterdam Methodology (GLEAM) [21], the Water Cycle Multi-mission Observation Strategy - Evapotranspiration (WACMOS-ET) [22,23], the Moderate Resolution Imaging Spectroradiometer (MODIS) Land Surface Evapotranspiration (MOD16) [24], and the Priestley-Taylor Jet Propulsion Laboratory (PT-JPL) [25], is based on vegetation indices as parameters for physically-based equations to estimate soil evaporation and vegetation transpiration. The second group, including the Surface Energy Balance Algorithm for Land (SEBAL) [26], the Mapping Evapotranspiration at high Resolution with Internalized Calibration (METRIC) [27], The Atmosphere-Land Exchange Inverse (ALEXI) [28], the operational Simplified Surface Energy Balance (SSEBop) [29], and the Surface Energy Balance System (SEBS) [30], uses $T_{S}$ to calculate $E T$ based on the surface energy balance conservation. Despite significant advances in ET modelling in the past decades at multiple temporal and spatial scales [31-33], several challenges remain to increase the accuracy of estimations [34-36] towards higher spatial and temporal resolution and larger spatial and temporal coverage and monitoring [1].

Among remote sensing-based ET algorithms, SEBAL [26] has been widely used worldwide and validated across multiple biomes and climate conditions [37-40], including cropland areas [31,41-43]). Its application is recommended for water resources management due to its ability to provide high resolution estimates of $E T[27,43]$. Although most SEBAL applications were performed in arid and temperate regions [17,44,45], its use in tropical climates also yielded accurate estimations [46-52].

To estimate $H$, SEBAL assumes a linear relationship between $d T$ and $T_{S}$ across a domain area, where $d T$ is designed as a vertical air temperature $\left(T_{a}\right)$ floating over the land surface, considering two extreme conditions [26,53]. At the hot and dry extreme conditions, $L E$ is zero and $H$ is equal to the available energy, whereas at the cold and wet extreme conditions, $H$ is zero and $L E$ is equal to the available energy. To solve the internal calibration, automatic calibration procedures were developed to select the endmembers, representing the hot and cold ends of the spectrum, using populations of endmember candidates from pre-defined ranges of $T_{S}$ and the normalized difference vegetation index (NDVI) [31,54]. Endmembers selected at well-watered areas are associated with low $T_{S}$ and high NDVI values, while endmembers selected at dry areas are associated with high $T_{S}$ and low NDVI values. Automated methods to select the endmembers provide consistent calibration when compared 
to manual calibration [55], especially for time-series analysis [54]. However, there is still a need to refine the endmembers selection process, which will further improve the model accuracy since ET estimations are sensitive to changes in endmembers [55-58].

Regional applications of the SEBAL are usually based on local meteorological measurements $[52,55,59,60]$, including wind speed $(u)$, relative humidity $(R H)$, and shortwave incident radiation $\left(R_{s}\right)$. On the other hand, large-scale $E T$ estimations can potentially benefit from the use of global, gridded meteorological variables (e.g., reanalysis methods) due to their global spatial coverage and long time-series $[17,21,24,61-63]$. In the case of reanalysis, data assimilation techniques are employed to combine global climatic models with observed data to improve the accuracy of global meteorological estimates [64-67]. For instance, Modern-Era Reanalysis for Research and Applications version 2 (MERRA-2) reanalysis was developed by the Global Modeling and Assimilation Office Project, providing consistent long-term meteorological datasets [68].

In the context of assessing techniques of automated ET time-series mapping and using global meteorological and remote sensing datasets, the goals of this study were to investigate how (1) the hot and cold endmembers selection and (2) the use of global reanalysis data as meteorological input impact the accuracy of the SEBAL in estimating the dry-season surface energy and water fluxes, when compared to eddy covariance measurements. We selected a transitional area between tropical rainforest and savanna in the southeastern part of the Amazon as the study area, with an experimental site located in a seasonal floodplain forest-savanna ecosystem. This area is characterized by a climatological 5-month dry season $[69,70]$, and is strongly affected by land cover conversion from forest and savanna to pasture and cropland [71].

\section{Materials and Methods}

\subsection{Research Overview}

To estimate surface energy fluxes, we first ran the SEBAL algorithm using ground measurements (SEBAL-T) and MERRA-2 reanalysis data as meteorological inputs (SEBAL-M). Landsat 5 Thematic Mapper (TM) data were used in both cases as remote sensing inputs. To assess uncertainties related to MERRA-2, we also compared MERRA-2 estimates to meteorological measurements. For validation, SEBAL estimations were assessed using measured radiative and turbulent fluxes. Subsequently, the averages of surface fluxes for each land cover class of the study area were quantified. A flowchart of the methodology is presented in Figure 1. Detailed information about the methodology is presented in the next sections.

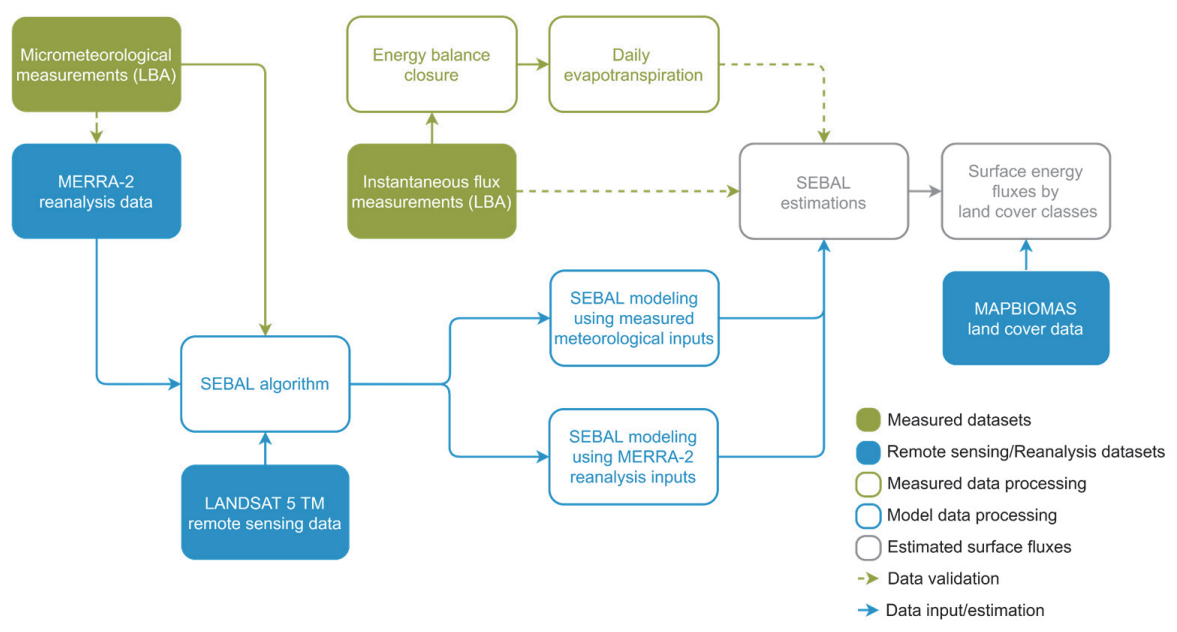

Figure 1. Flowchart of the methodology to estimate surface energy and water fluxes based on meteorological measurements, Modern-Era Reanalysis for Research and Applications version 2 (MERRA-2) reanalysis data, and Landsat 5 remote sensing images. 


\subsection{Micrometeorological and Eddy Covariance Measurements}

The micrometeorological and eddy covariance tower is located at $9^{\circ} 49^{\prime} 16.1^{\prime \prime} \mathrm{S}$ and $50^{\circ} 08^{\prime} 55.3^{\prime \prime} \mathrm{W}$, in a transitional area between the Amazon and the Cerrado biomes (Figure 2), at the northern boundary of the Bananal island, between the Araguaia and Javaés rivers, over a seasonal forest-savanna ecosystem floodplain. Natural vegetation within the tower footprint is composed mostly of woodland savanna (with trees up to $18 \mathrm{~m}$ and sparse bushes) and fragments of wooded savanna (with trees up to $5 \mathrm{~m}$ ) and grassland, with a 5-month dry season (May to September) and a 3-month flood season (January to March) $[69,70]$. The climate is defined as tropical with a dry winter (Aw Koppen's climate classification) [72], with annual precipitation around $1755 \mathrm{~mm}$ and $90 \%$ of the precipitation during the wet season, causing seasonal flooding [73].

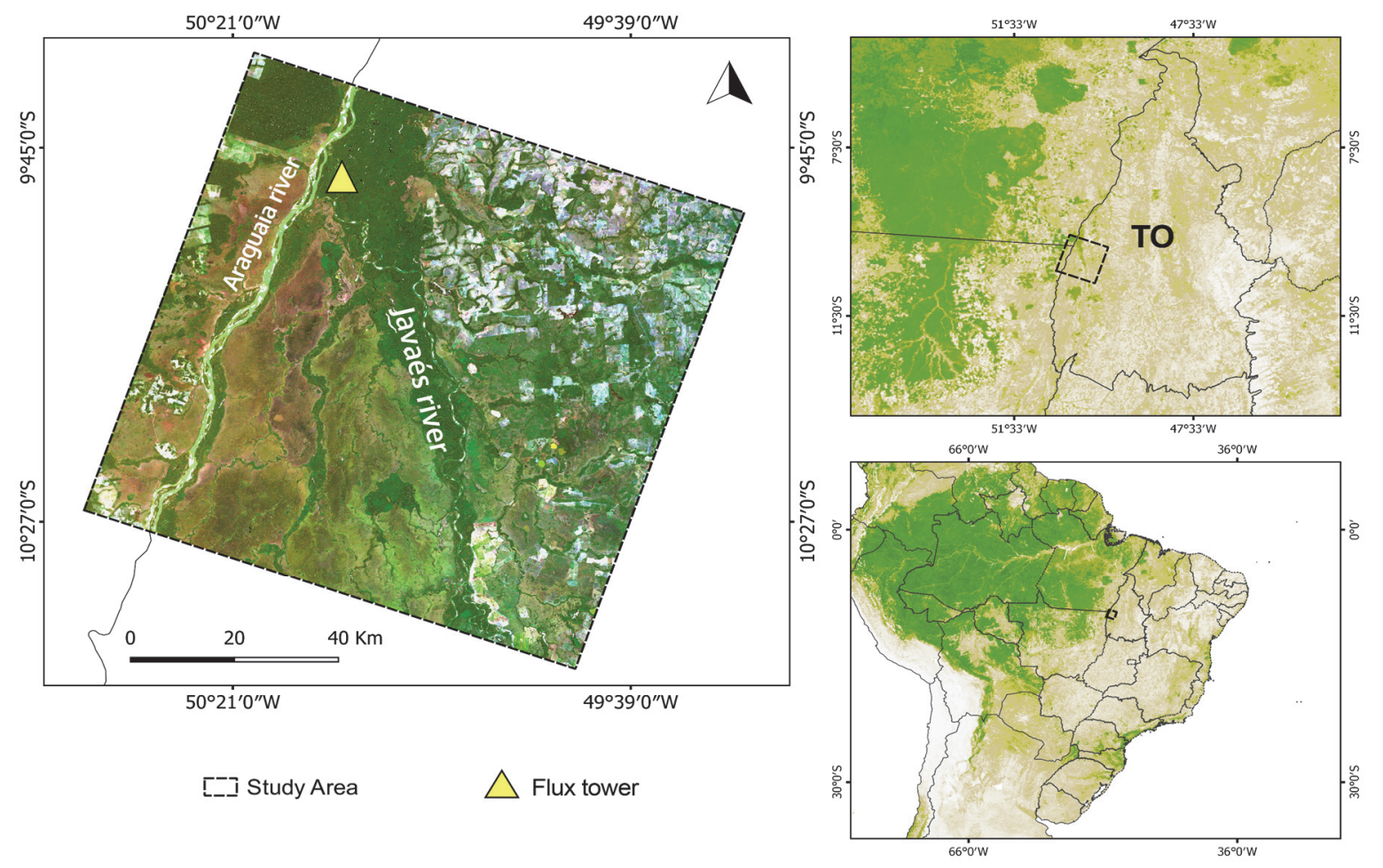

Figure 2. Characterization of the transitional area between tropical forest and savanna vegetation in the Brazilian state of Tocantins (TO) and location of the eddy covariance measurements at the Bananal Javaés (JAV) site (flux tower), using the Landsat 5 image path-row 223-067 from July 2005 (left). MODIS tree cover fraction is used to illustrate the large-scale vegetation spatial pattern (right).

Micrometeorological and eddy covariance measurements at the Bananal Javaés site (JAV), available from 10/2003 to 12/2006, are part of the Large-Scale Biosphere and Atmosphere Experiment in the Amazon (LBA) [74], reported in da Rocha et al. [70]. LBA is an international research program focused on understanding the interactions between terrestrial ecosystems and the atmosphere within a region of great human and natural complexity (encompassing a wide range of land-use and land-cover types and climate conditions) on the Amazon biome [75]. Data from the JAV site have been described $[69,70,76]$ in terms of their environmental characteristics, instrumentation (Table 1), measurement procedures, and results. We used quality-controlled data from Saleska et al. [77], recorded above the canopy at 30 min intervals, to perform our analysis. We did not gap fill the data.

The energy balance closure (defined as $R_{n}-G=H+L E$, where $G$ is the ground heat flux and $R_{n}$ is the net radiation) at several LBA sites presented an imbalance of $70 \%-105 \%$ [70] due to systematic biases in instruments, energy sources not considered, as well as losses of turbulent fluxes at high and low frequencies [78]. For the JAV site, during the dry season, the energy balance closure presented a 
negative imbalance of $15 \%$ [70]. Therefore, the energy balance closure was forced using the Bowen ratio $(\beta)$ technique (Equation (1)). The residual available energy was then distributed between $H$ and $L E$, and the energy imbalance was closed to conserve the energy partitioning, according to Equations (2) and (3) [79]. This simple and reliable approach, used in a wide range of climates [80], was adopted since it can perform similarly to other methods, despite remaining uncertainties about energy balance closure [81].

$$
\begin{gathered}
\beta=\frac{H}{L E} \\
H=\frac{\beta(R n-G)}{1+\beta} \\
L E=\frac{R n-G}{1+\beta}
\end{gathered}
$$

Table 1. Description of micrometeorological and eddy covariance instrumentation.

\begin{tabular}{cc}
\hline Variable & Instrumentation \\
\hline Air temperature & HMP45C Vaisalla (Campbell Scientific) \\
Relative humidity & HMP45C Vaisalla (Campbell Scientific) \\
Wind speed & Met One 014 (Campbell Scientific) \\
Soil heat flux & REBS HFT 3.1 (Campbell Scientific) \\
Net radiation & NR Lite Net radiometer (Campbell Scientific) \\
Surface fluxes & Li-Cor 7500 (Li-Cor) \\
\hline
\end{tabular}

\subsection{MERRA-2 Meteorological Reanalysis Data}

As global gridded reanalysis inputs, we used reanalysis data from MERRA-2, with spatial resolution of $0.5^{\circ} \times 0.625^{\circ}$ and hourly temporal resolution [68]. Meteorological reanalysis inputs include daily average $R_{s}$ and hourly $T_{a}$ (average between 10:00 and 11:00 am local time to coincide with the satellite overpass), $u$, specific humidity $(q)$, and atmospheric pressure $(P)$. MERRA-2 RH was computed from $q$, according to Equations (4)-(6) [82]. To combine meteorological reanalysis and remote sensing inputs, MERRA-2 data were interpolated from coarse spatial resolution to match the spatial resolution of Landsat images $(30 \mathrm{~m}$ ) using a simple bicubic interpolation method (MATLABßR2012b).

$$
\begin{gathered}
q=0.622 \frac{e}{P} \\
e_{S}=0.6108 \exp \left(\frac{17.27-T}{237.3+T}\right) \\
R H=100 \frac{e}{e_{S}}
\end{gathered}
$$

where $e$ and $e_{S}$ are vapor pressure and saturated vapor pressure, respectively, while $P$ is the atmospheric pressure.

\subsection{Landsat Data}

Landsat 5 TM images were selected periodically during the dry season (June to September), with consideration given to cloud-cover condition and micrometeorological and eddy covariance measurements availability. After excluding images with greater than $10 \%$ cloud cover, a total of 12 images were obtained (Table 2). Landsat images have a temporal resolution of 16 days and a spatial resolution of $30 \mathrm{~m}$ for multispectral data and $120 \mathrm{~m}$ for thermal data. We used Landsat data because of the high spatial resolution and data availability during the eddy covariance measurements, encompassing the 2004-2006 dry seasons. To compute SEBAL variables we used bands 1 to 7 and to select high confidence pixels we used the quality attributes band. 
Table 2. Description of the Landsat 5 Thematic (TM) images used to implement the Surface Energy Balance Algorithm for Land (SEBAL).

\begin{tabular}{cccc}
\hline Date & DOY ${ }^{1}$ & Landsat ID & Cloud Cover \\
\hline 16/Jun/2004 & 168 & LT05_L1TP_223067_20040616_20161130_01_T1 & $0 \%$ \\
02/Jul/2004 & 184 & LT05_L1TP_223067_20040702_20161201_01_T1 & $0 \%$ \\
18/Jul/2004 & 200 & LT05_L1TP_223067_20040718_20161130_01_T1 & $0 \%$ \\
04/Sep/2004 & 248 & LT05_L1TP_223067_20040904_20161129_01_T1 & $0 \%$ \\
18/May/2005 & 138 & LT05_L1TP_223067_20050518_20161126_01_T1 & $0 \%$ \\
03/Jun/2005 & 154 & LT05_L1TP_223067_20050603_20161125_01_T1 & $0 \%$ \\
05/Jul/2005 & 186 & LT05_L1TP_223067_20050705_20161126_01_T1 & $0 \%$ \\
21/Jul/2005 & 202 & LT05_L1TP_223067_20050721_20161125_01_T1 & $0 \%$ \\
06/Jun/2006 & 157 & LT05_L1TP_223067_20060606_20161121_01_T1 & $0 \%$ \\
22/Jun/2006 & 173 & LT05_L1TP_223067_20060622_20161121_01_T1 & $1 \%$ \\
08/Jul/2006 & 189 & LT05_L1TP_223067_20060708_20161120_01_T1 & 2\% \\
10/Sep/2006 & 253 & LT05_L1TP_223067_20060910_20161119_01_T1 & $3 \%$ \\
\hline & & 1 DOY: Day of the year. &
\end{tabular}

\subsection{Surface Energy Balance Algorithm for Land (SEBAL)}

SEBAL calculates instantaneous $L E$ at the moment of satellite overpass (around 10:30 am local time) as the residual in the surface energy balance Equation (Equation (7)).

$$
L E=R n-H-G
$$

$G$ was computed based on Bastiaanssen [83] (Equation (8)), assuming a relationship with $R_{n}, T_{s}$, $\alpha$, and NDVI.

$$
\frac{G}{R n}=\frac{T_{s}}{\alpha}\left(0.0038 \alpha+0.0074 \alpha^{2}\right)\left(1-0.98 N D V I^{4}\right)
$$

where $\alpha$ is the surface albedo, estimated following Tasumi et al. [84] (Equation (9)) using instantaneous Landsat surface reflectances to retrieve maximum spatial fidelity.

$$
\alpha=\sum\left(\omega_{\lambda} * \rho_{\lambda}\right)
$$

where $\omega_{\lambda}$ is a coefficient related to the ratio of the solar radiation at the surface occurring within a given spectral band and $\rho_{\lambda}$ is the surface reflectance for this band.

To estimate $T_{s}$ based on Landsat images, we used the modified Planck Equation (Equation (10)), following Allen et al. [27], with atmospheric and surface emissivity corrections.

$$
T_{s}=\frac{K_{2}}{\ln \left[\left(\frac{\varepsilon_{N B} K_{1}}{R_{c}}\right)+1\right]}
$$

where $\varepsilon_{N B}$ is the surface emissivity corresponding to the thermal sensor wavelength, $R_{c}$ is the corrected thermal radiance from the surface based on the spectral radiance (Landsat band 6), while $K_{1}$ and $K_{2}$ are constants [27].

To estimate $H$ (Equation (11)) it is necessary to select endmembers to represent extreme conditions for internal calibration [26]. Based on the hot and cold endmembers selection, SEBAL considers a linear relation between $T_{s}$ and $d T$ between two heights $z_{1}$ and $z_{2} . H$ is assumed to be zero for the cold pixel and maximum for the hot pixel, while $L E$ is assumed to be zero for the hot pixel and maximum for the cold pixel.

$$
H=\frac{\rho C p d T}{r_{a h}}
$$

where $\rho$ is the air density, $C p$ is the specific heat capacity of air, and $r_{a h}$ is the aerodynamic resistance to turbulent heat transport from the evaporating surface at height $z_{1}$ to the air above the evaporating surface 
$z_{2}$ (Equation (12)), considering the atmospheric stability correction based on the Monin-Obhukov similarity hypothesis [26].

$$
r_{a h}=\frac{\ln \frac{z_{2}}{z_{1}}}{u * k}
$$

where $k$ is the von Karman constant (0.41) and $u *$ the friction velocity, estimated for each pixel (Equation (13)).

$$
u *=\frac{u_{200} k}{\ln \left(\frac{200}{Z_{o m}}\right)}
$$

where $u_{200}$ is wind speed at $200 \mathrm{~m}$ and $z_{\text {om }}$ is the surface roughness for each pixel, estimated according to Bastiaanssen [83].

To select the hot and cold endmembers, we used a simplified version adapted from the automated methodology from METRIC [27] based on the Calibration using Inverse Modeling at Extreme Conditions (CIMEC) process [54]. The CIMEC process employs a population of candidate members based on quantiles of remote sensing estimations of $T_{S}$ and NDVI to select the hot (dry) and cold (wet) ends of the ET spectrum, aiming at consistent internal calibration for time-series applications. Allen et al. [54] defined a subset of endmembers within the highest $5 \%$ of NDVI and the lowest $20 \%$ of $T_{S}$ to select the cold extreme condition, while endmembers within the lowest $10 \%$ NDVI and with the highest $20 \% T_{s}$ were used to select the hot extreme condition. After [54], several additional criteria were proposed to improve and refine the endmember selection, sometimes with an increase in complexity and time processing $[17,31,55,56,85]$. In this research, we proposed an assessment of the automated calibration of the endmembers based on the Allen et al. [54] methodology to accurately select the quantiles to estimate the surface energy components. We tested for the effect of nine different automated endmember selection quantiles (Table 3) over an area of $100 \times 100 \mathrm{~km}$, based solely on $T_{s}$ and NDVI, without additional filters. The first quantile group was proposed by Allen et al. [54]. For the other eight groups we used different quantiles to select the endmembers.

Table 3. Quantiles used for the automated selection of cold and hot endmembers.

\begin{tabular}{cccccc}
\hline \multicolumn{2}{c}{ Endmember Group } & NDVI Cold & $\boldsymbol{T}_{\boldsymbol{s}}$ Cold & NDVI Hot & $\boldsymbol{T}_{\boldsymbol{s}}$ Hot \\
\hline 1 & $\left(g_{A}\right)$ & $5 \%$ & $20 \%$ & $10 \%$ & $20 \%$ \\
2 & $\left(g_{T s 1}\right)$ & $5 \%$ & $10 \%$ & $10 \%$ & $10 \%$ \\
3 & $\left(g_{T s 2}\right)$ & $5 \%$ & $1 \%$ & $10 \%$ & $1 \%$ \\
4 & $\left(g_{T s 3}\right)$ & $5 \%$ & $0.1 \%$ & $10 \%$ & $0.1 \%$ \\
5 & $\left(g_{T s 4}\right)$ & $5 \%$ & $0.01 \%$ & $10 \%$ & $0.01 \%$ \\
6 & $\left(g_{V I 1}\right)$ & $3 \%$ & $20 \%$ & $7 \%$ & $20 \%$ \\
7 & $\left(g_{V I 2}\right)$ & $2 \%$ & $20 \%$ & $4 \%$ & $20 \%$ \\
8 & $\left(g_{V I 3}\right)$ & $1.5 \%$ & $20 \%$ & $3 \%$ & $20 \%$ \\
9 & $\left(g_{V I 4}\right)$ & $1 \%$ & $20 \%$ & $2 \%$ & $20 \%$ \\
\hline
\end{tabular}

To estimate the daily average net radiation $\left(R_{n 24 h}\right)$ we used the methodology proposed by de Bruin [86] (Equation (14)).

$$
R_{n_{24 h}}=(1-\alpha) * R_{s_{24 h}}-C_{s} * \frac{R_{s_{24 h}}}{R_{a_{24 h}}}
$$

where $R_{s_{24 h}}$ is the shortwave incident daily radiation, $R_{a_{24 h}}$ is the exoatmospheric shortwave radiation, while $C_{s}$ is an empirical constant, calibrated according to local climate conditions. We used a generalized reduced gradient nonlinear method for calibration [87], yielding a value of 115 for clear-sky days and atmospheric conditions similar to the cloud-free Landsat image conditions, reducing the influence of low atmospheric transmissivity during all sky conditions. 
The evaporative fraction $(\Lambda)$ (Equation (15)) was used to upscale instantaneous estimates of $L E$ to daily $E T\left(E T_{24 h}\right)$ (Equation (16)), assuming that $\Lambda$ is constant during the daytime [26], when soil moisture does not change significantly and advection does not occur [40].

$$
\begin{gathered}
\Lambda=\frac{L E}{R n-G} \\
E T_{24 h}=\frac{\Lambda R_{n_{24 h}}}{\lambda}
\end{gathered}
$$

where $\lambda$ is the latent heat of vaporization of water [82].

\subsection{MapBiomas Land Cover Dataset}

To assess the spatial variations of surface energy and water fluxes over the main land cover conditions in the study area, we used a land cover classification from MapBiomas version 3.1. MapBiomas is a collaborative network to generate annual land-use and land-cover maps in Brazil with spatial resolution of $30 \mathrm{~m}$ through processing of the Landsat collection (1985-2018) with a random forest algorithm within Google Earth Engine cloud computing [88], available at http://mapbiomas.org.

\subsection{MERRA-2 and SEBAL Assessment}

To evaluate MERRA-2 meteorological reanalysis data and to validate SEBAL surface fluxes, we used the performance metrics of mean absolute error (MAE) and root mean square error (RMSE) between observed $\left(O_{i}\right)$ and predicted $\left(P_{i}\right)$ values (Equations (17) and (18)). Ground measurements were used to validate a single MERRA-2 coarse pixel (for the location of the JAV site) and to validate SEBAL, considering an average estimation for an area centered in the JAV site with a radius of $1 \mathrm{~km}$. This average was adopted based on the tower footprint, since in both wet and dry seasons, up to $75 \%$ of the footprint flux originates within $1 \mathrm{~km}$ of the flux tower radius [69].

$$
\begin{gathered}
M A E=\frac{\sum\left|P_{i}-O_{i}\right|}{n} \\
R M S E=\sqrt{\frac{\sum\left(O_{i}-P_{i}\right)^{2}}{n}}
\end{gathered}
$$

where $n$ is the number of samples.

\section{Results}

\subsection{Validation of MERRA-2 Reanalysis Data}

To assess MERRA-2 meteorological reanalysis accuracy and uncertainties in SEBAL surface flux estimations, we compared $T_{a}, R_{s}, R H$, and $u$ to ground measurements (Figure 3). For $R_{s}$, we found an overestimation (MAE) of $35.8 \mathrm{~W} \mathrm{~m}^{-2}$ and an error (RMSE) of $40.8 \mathrm{~W} \mathrm{~m}^{-2}$, representing $17.0 \%$ and $19.4 \%$ of the average measured $R_{S}$, respectively. Overall, MERRA- $2 R_{S}$ errors are similar in range during both wet and dry seasons. For $u$ and $R H$ we also found an overestimation. Whereas for $u$, MAE was $1.3 \mathrm{~m} \mathrm{~s}^{-1}$ and RMSE was $1.6 \mathrm{~m} \mathrm{~s}^{-1}$, for $R H$ we found $15.7 \%$ and $18.3 \%$, respectively, with higher errors during the dry season and an overestimation lag of 2 to 3 months since the beginning of the dry season. On the other hand, for $T_{a}$ we found an underestimation (MAE) of $3.9^{\circ} \mathrm{C}$ and an RMSE of $4.7^{\circ} \mathrm{C}$, with higher underestimation during the dry season, yielding RMSE up to $6.2^{\circ} \mathrm{C}$. During the wet (flooded) season, MAE and RMSE decreased to 2.4 and $2.8^{\circ} \mathrm{C}$, respectively. 

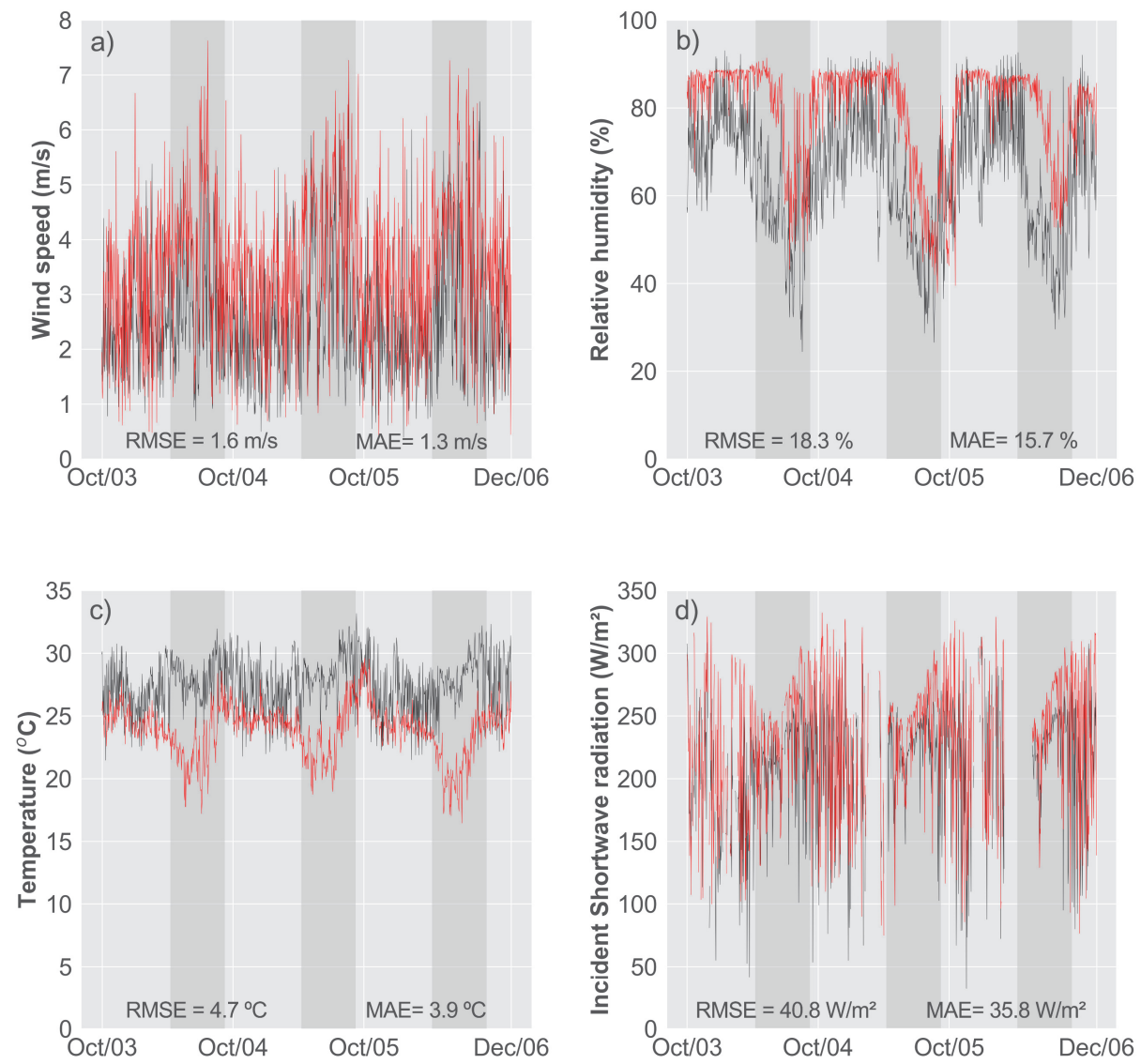

Merra-2 $\longrightarrow$ in-situ

Figure 3. Comparison of hourly (average between 10:00 and 11:00 am) wind speed $(u)(a)$, relative humidity $(R H)(\mathbf{b})$, air temperature $\left(T_{a}\right)(\mathbf{c})$, and daily incident shortwave radiation $\left(R_{s}\right)$ (d) between MERRA-2 and meteorological measurements at the JAV site. Shaded areas represent the climatological dry season.

\subsection{Validation of SEBAL Instantaneous Surface Flux Estimates}

For performance assessment, the instantaneous surface fluxes $\left(R_{n}, G, H\right.$, and $\left.L E\right)$ estimated by SEBAL-T and SEBAL-M averaged over the $1 \mathrm{~km}$ radius area (tower footprint) were compared against radiative and eddy covariance measured data (at 10:30 am local time) at the JAV site. Results of nine different quantiles of endmembers (combinations of $T_{s}$ and NDVI quantiles) are shown in Figure 4. For $R_{n}$, SEBAL-M yielded higher accuracy estimates, with MAE ranging between 11.9 and $13.3 \mathrm{~W} \mathrm{~m}^{-2}$ and RMSE ranging between 15.6 and $17.6 \mathrm{~W} \mathrm{~m}^{-2}$. SEBAL-T had a MAE between 14.8 and $17.6 \mathrm{~W} \mathrm{~m}^{-2}$ and RMSE between 18.7 and $21.2 \mathrm{~W} \mathrm{~m}^{-2}$. For both meteorological inputs, the best endmember quantile was $g_{V I 4}$. For $G$, both methods (SEBAL-M and SEBAL-T) yielded similar overestimations, with average MAE of 108.3 and $108.9 \mathrm{~W} \mathrm{~m}^{-2}$ and RMSE of 109.3 and $110.0 \mathrm{~W} \mathrm{~m}^{-2}$, respectively.

Despite similar results for $R_{n}$ and $G$ estimations using different meteorological datasets and quantiles to select the endmembers, we found notable differences in $H$ and $L E$ estimations, mainly related to the endmember selection criteria. The average $H$ measurement without energy balance closure was $40.9 \mathrm{~W} \mathrm{~m}^{-2}$, and the average $H$ from SEBAL-T estimations measurements ranged between 19.0 and $45.8 \mathrm{~W} \mathrm{~m}^{-2}$ for quantiles $g_{A}-g_{T s 4}$, yielding an average of $19.1 \mathrm{~W} \mathrm{~m}^{-2}$ for quantiles $g_{I V 1}-g_{I V 4}$. SEBAL-M estimations were slightly higher than SEBAL-T ones, ranging between 25.0 and $68.4 \mathrm{~W} \mathrm{~m}^{-2}$ for quantiles $g_{A}-g_{T s 4}$, with an average of $21.91 \mathrm{~W} \mathrm{~m}^{-2}$ for quantiles $g_{I V 1}-g_{I V 4}$. When considering the energy balance closure, the average $H$ measurement increased to $79.9 \mathrm{~W} \mathrm{~m}^{-2}$. Without energy balance closure, for SEBAL-T (SEBAL-M) MAE ranged between 22.7 (21.4) and 29.9 (34.5) $\mathrm{W} \mathrm{m}^{-2}$ and RMSE between 30.0 (30.0) and $48.9 \mathrm{~W} \mathrm{~m}^{-2}$ (56.2). The best endmember quantile for the most 
accurate estimates of instantaneous $H$ was $g_{T s 2}$ for SEBAL-T and $g_{T_{s} 1}$ for SEBAL-M, with an RMSE around $30.0 \mathrm{~W} \mathrm{~m}^{-2}$. Considering the energy balance closure, MAE and RMSE increased for SEBAL-T (SEBAL-M), ranging between 38.7 (62.4) and 37.3 (60.5) $\mathrm{W} \mathrm{m}^{-2}$ for MAE and between 51.3 (70.1) and 50.0 (67.9) $\mathrm{W} \mathrm{m}^{-2}$ for RMSE, with quantile $g_{T s 4}$ yielding higher accuracy using both meteorological datasets as inputs.
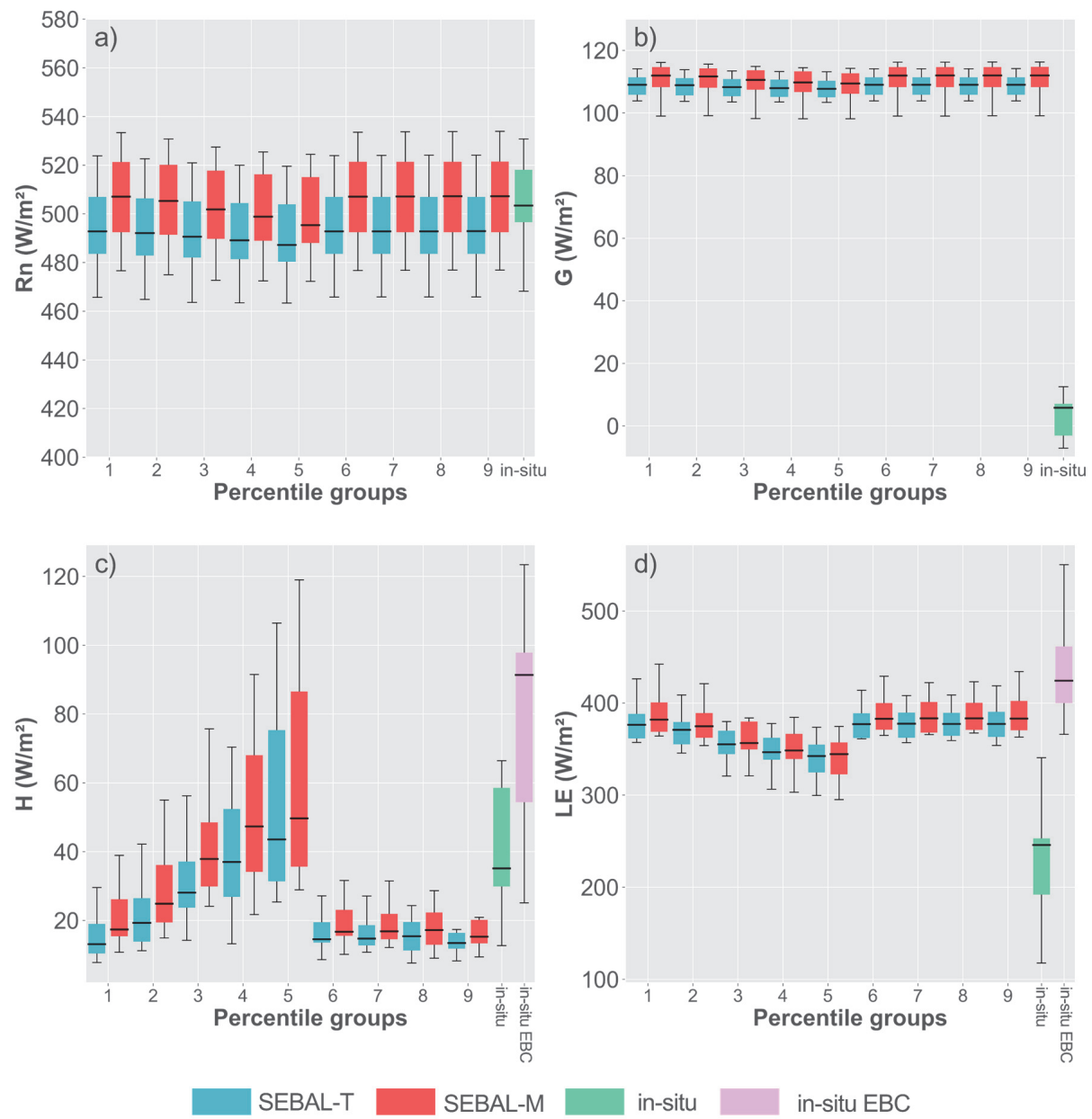

Figure 4. Comparisons of instantaneous surface energy fluxes (net radiation $\left(R_{n}\right)(\mathbf{a})$, soil heat $(G)(\mathbf{b})$, sensible heat $(H)(\mathbf{c})$, and latent heat $(L E)(\mathbf{d}))$ between ground measurements (where in situ stands for measurements without energy balance closure and in situ EBC for measurements with energy balance closure) and SEBAL estimations driven by meteorological measurements (SEBAL-T) and MERRA-2 (SEBAL-M) for nine quantile groups of endmember selection at the JAV site.

With an increase in $H$ estimations (for both meteorological inputs) for quantiles $g_{A}-g_{T s 4}$, $L E$ estimations decreased for the same quantiles and held steady for quantiles $g_{I V 1}-g_{I V 4}$. Overall, without energy balance closure, instantaneous $L E$ was overestimated, with MAE (RMSE) ranging between 111.6 (128.1) and 156.3 (169.9) $\mathrm{W} \mathrm{m}^{-2}$ for SEBAL-T and between 95.8 (98.7) and 149.3 (152.0) $\mathrm{W} \mathrm{m}^{-2}$ for SEBAL-M. When correcting instantaneous measurements of $L E$ according to the energy balance closure, $L E$ increased accuracy, with an underestimation, with MAE (RMSE) ranging between 52.3 (66.0) and 97.1 (113.1) $\mathrm{W} \mathrm{m}^{-2}$ for SEBAL-T and between 89.5 (93.9) and 143.0 (144.5) $\mathrm{W} \mathrm{m}^{-2}$ for SEBAL-M. As a residual of the energy balance, instantaneous estimates of $L E$ for quantiles $g_{A}$ and $g_{I V 1}-g_{I V 4}$ yielded the most accurate estimates. MAE and RMSE of all estimated quantiles for $R n, G$, $H$, and $L E$ are presented in Tables S1 and S2. 


\subsection{Assessment of SEBAL Daily Evapotranspiration Estimates}

SEBAL upscaling from instantaneous fluxes of $L E$ to daily $E T\left(E T_{24 h}\right)$ integrates the daily net radiation $\left(R_{n_{24 h}}\right)$, assuming $\Lambda$ as a constant indicator of energy partitioning throughout the day (from sunrise to sunset). To investigate SEBAL upscaling, the accuracy of the estimated $\Lambda$ was first assessed in relation to the measured data for instantaneous and daily measurements (considering or not the energy balance closure). Then, $R_{n_{24 h}}, \Lambda$, and $E T_{24 h}$ estimates were evaluated (Figure 5). SEBAL based $\Lambda$ led to overestimation for the nine quantile groups when compared to instantaneous $\Lambda$ computed from measured data (at 10:30 am local time). However, when it was compared to the daily $\Lambda$ computed from measured daily averages, the accuracy increased significantly for both meteorological inputs. For instantaneous $\Lambda$ we found an average of $0.44 \pm 0.14$ (mean \pm standard deviation), while for daily average $\Lambda$ (measured) we found $0.75 \pm 0.16$ (without energy balance closure) and $0.82 \pm 0.05$ (forcing the energy balance closure). For SEBAL-T estimates, $\Lambda$ values ranged between 0.76 and 0.96 and for SEBAL-M, $\Lambda$ ranged between 0.74 and 0.95 . For the most accurate SEBAL estimates of $\Lambda$, quantile $g_{\text {Ts } 3}$, we found an RMSE of $0.08(0.19)$ and $0.10(0.20)$, with (without) daily energy balance closure, for SEBAL-M and SEBAL-T estimations, respectively. Overall, SEBAL estimates of instantaneous $\Lambda$ were relatively close to daily ground measurements when considering the energy balance closure. Furthermore, $R_{n_{24 h}}$ estimates yielded high accuracy when driven by both meteorological inputs. Overall, an underestimation was obtained, with an RMSE of $13.5 \mathrm{~W} \mathrm{~m}^{-2}$ for SEBAL-T and $9.8 \mathrm{~W} \mathrm{~m}^{-2}$ for SEBAL-M. MAE and RMSE of all quantiles for $\Lambda$ and $E T_{24 h}$ are presented in Tables S3 and S4.

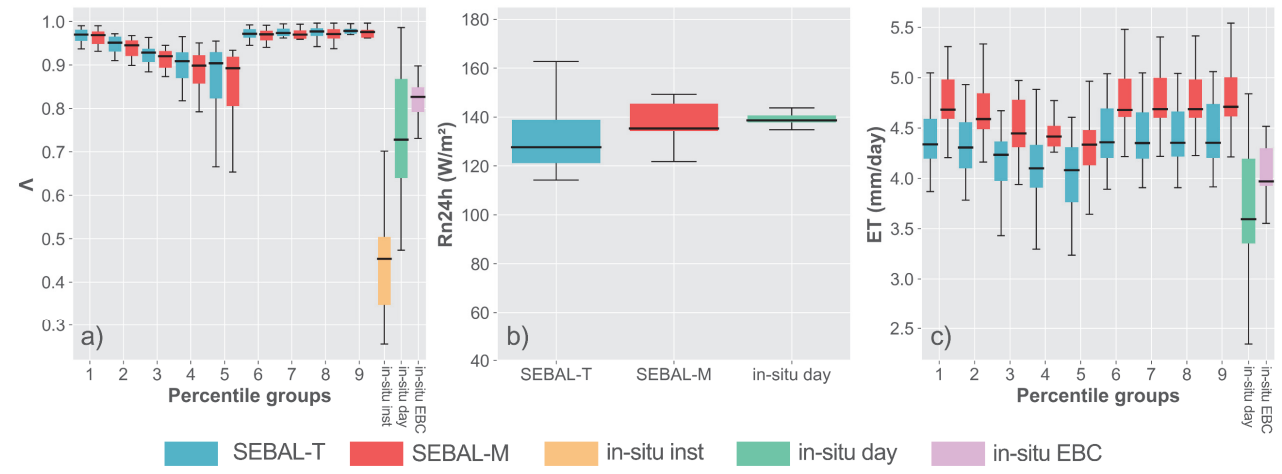

Figure 5. Comparison between ground measurements (where in situ inst and day stand for instantaneous and daily measurements without energy balance closure, respectively, and in situ EBC for daily measurements with energy balance closure) and SEBAL estimates of evaporative fraction $(\Lambda)(\mathbf{a})$, daily net radiation $\left(R_{n_{24 h}}\right)(\mathbf{b})$, and daily evapotranspiration $\left(E T_{24 h}\right)(\mathbf{c})$ driven by in situ meteorological measurements (SEBAL-T) and MERRA-2 (SEBAL-M).

Our results indicate that daily estimates of $E T$ using the SEBAL algorithm and both meteorological inputs were consistently accurate when compared to eddy covariance measurements. Without the energy balance closure, SEBAL-T led to an average RMSE of $0.87 \mathrm{~mm} \mathrm{day}^{-1}$ (for SEBAL-M we found an RMSE of $0.85 \mathrm{~mm} \mathrm{day}^{-1}$ ). On the other hand, when using the energy balance closure technique to compute daily ET, SEBAL accuracy increased significantly, yielding an average RMSE of $0.35 \mathrm{~mm}$ day $^{-1}$ for both meteorological inputs (an improvement of $60 \%$ ). The most accurate quantile used for the endmember selection was $g_{T s 4}$, with NDVI of $5 \%$ and $10 \%$ and $T_{s}$ of $0.01 \%$, for cold and hot endmembers, respectively, representing an error of $8.6 \%$ (RMSE compared to the average daily ET), with errors up to $15 \%$ and $23 \%$ for the less accurate quantile of endmembers selection, for SEBAL-T and SEBAL-M, respectively.

\subsection{Spatial Assessment of Surface Energy and Water Fluxes}

Based on the combination of MERRA-2 reanalysis and Landsat images SEBAL estimations, we computed the average of each surface energy $(H$ and $L E)$ and water $(E T)$ flux component according 
to land cover, using data from MapBiomas [88]. The study area presents a large heterogeneity in vegetation physiognomies, dominated by savanna vegetation, with an significant increase in croplands $[9,89,90]$. To illustrate the spatial pattern of vegetation characteristics and surface processes, we computed the dry season average NDVI and $T_{s}$ and daily ET for 2004 (Figure 6). NDVI values larger than zero were found over forested areas (flooded or non-flooded), which are associated to $T_{s}$ values lower (close to the minimum $24.5^{\circ} \mathrm{C}$ values) than savanna and croplands, which reached up to $32{ }^{\circ} \mathrm{C}$ and also yielded a higher $H$ proportion in the energy partition. The largest $T_{S}$ values were obtained for croplands, while natural savanna regions reached intermediate values. There are marked differences between tropical forest, savanna vegetation, and cropland areas with respect to land-atmosphere exchanges. Converting forest vegetation to cropland and pasture substantially changes surface energy ( $H$ and $L E$ ) and water (ET) fluxes (Figure 7). Taking into consideration the average surface fluxes according to land cover classes for all analyzed images and using SEBAL-T results from $g_{T s 4}$ quantile, our estimates of daily $E T$ ranged between 2.0 and $4.2 \mathrm{~mm}$ day $^{-1}$ for pasture and tropical forest, while grassland, savanna vegetation, and cropland presented rates of 2.9, 3.1, and $3.2 \mathrm{~mm} \mathrm{day}^{-1}$, respectively. Finally, Figure 8 presents the fraction of $H$ and $L E$ for different tiles across the study area (the size of each chart relates to the sum of $H$ and $L E$ for the year 2004 day of the year (DOY) 200 image). While in forest areas, the main component is $L E$, in cropland and pasture lands, there is a considerable increase in $H$ and decrease in $L E$.
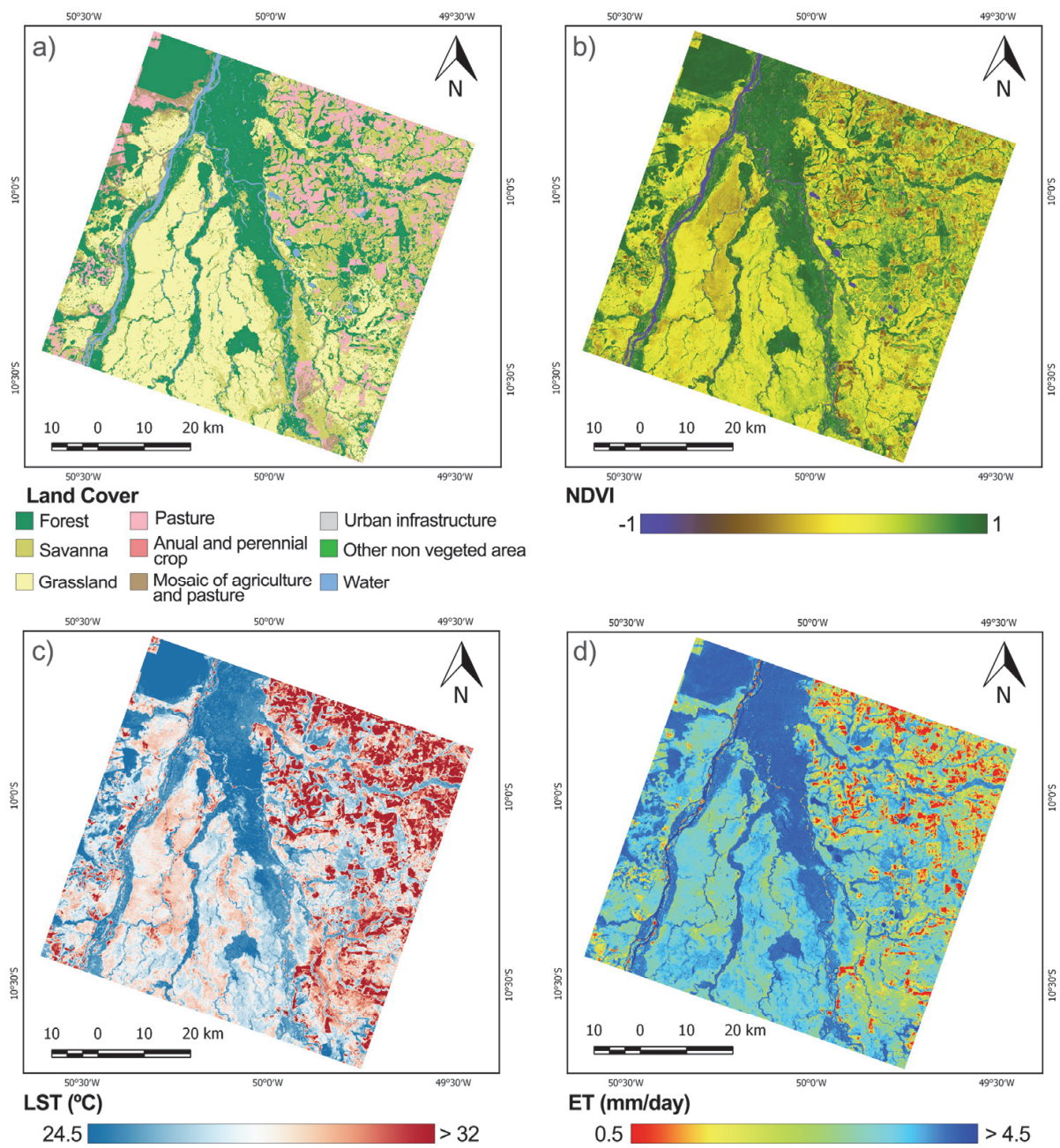

Figure 6. Spatial patterns of land cover (a) and the dry season average of vegetation index (NDVI) (b), surface temperature $\left(T_{S}\right)(\mathbf{c})$, and daily evapotranspiration $(E T)(\mathbf{d})$ in the study area for the year 2004 DOY 200. 


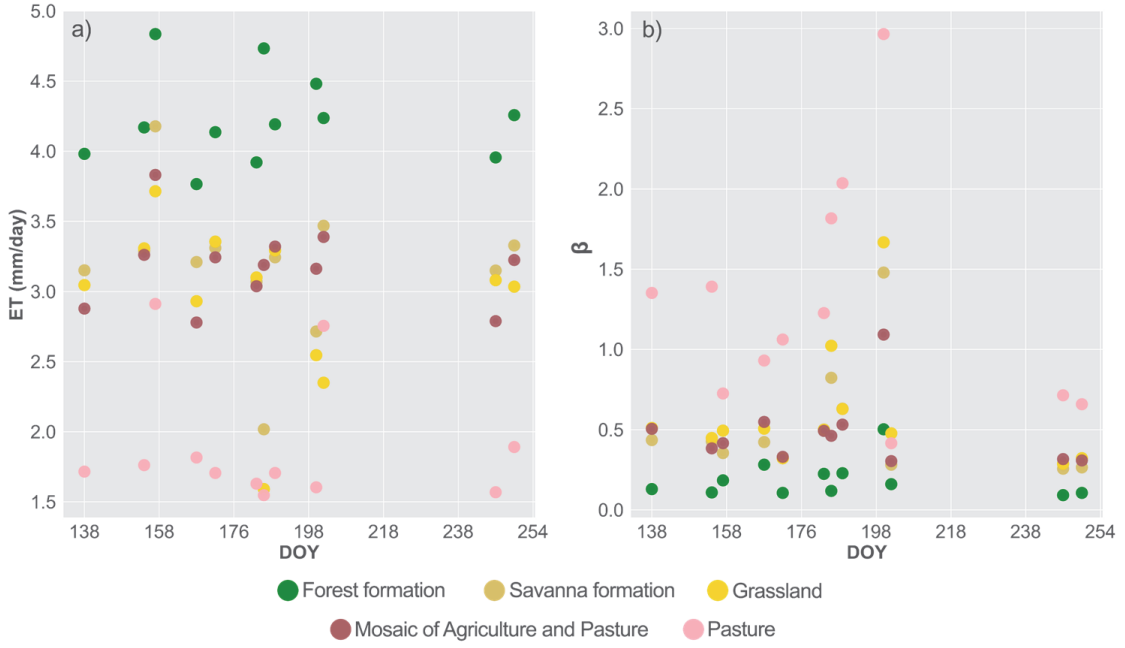

Figure 7. Dry season temporal variability of daily evapotranspiration $(E T)($ a) and Bowen ratio $(\beta)$ (b) for all analyzed images from SEBAL-T results using $g_{T s 4}$ quantile. Values were averaged for each MapBiomas land class during 2004-2006.

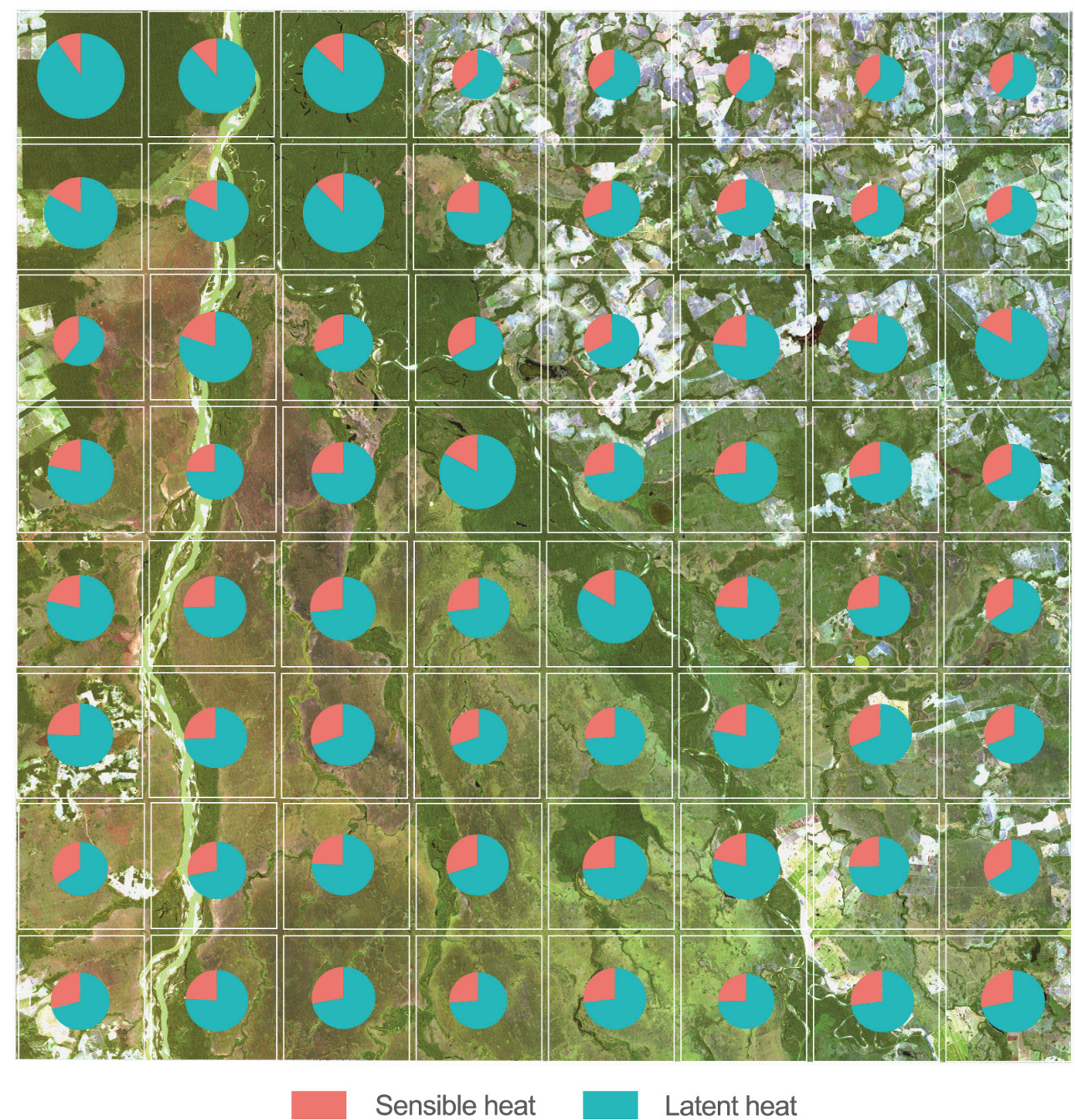

Figure 8. Average surface-energy-fluxes partitioning between sensible $(H)$ and latent $(L E)$ heat according to changes in vegetation physiognomies using SEBAL-T results with $g_{T s}$ quantile for the year 2004 DOY 200. 


\section{Discussions}

\subsection{Uncertainties in the SEBAL Model Structure}

Our estimates of instantaneous $R_{n}$ are consistent with other studies [91], with errors lower than $5 \%$, despite overestimations when driven by MERRA- 2 and underestimations when driven by ground measurements. However, we found considerable discrepancies in instantaneous $G$ values, with RMSE higher than $108 \mathrm{~W} \mathrm{~m}^{-2}$. Measured $G$ represented only a small fraction of $R_{n}$, corresponding to around $3 \%$ of this component $\left(7 \mathrm{~W} \mathrm{~m}^{-2}\right.$ on average). Results from [92] indicate that the canopy and air-column heat storage in the Amazon during the dry season is around $80 \mathrm{~W} \mathrm{~m}^{-2}$ during mid-morning, being much higher than $G$. Since canopy heat storage plays an important role on a diurnal time scale, it cannot be neglected, despite its integration on a daily time scale only accounting for a small portion of the available energy [93]. On a daily basis, heat gained during the daytime is released at night through thermal radiation and evaporation [94].

The poor performance of the SEBAL in estimating $G$ may also be related to the forest-savanna flooding ecosystem, since the equation used to calculate $G$ was derived for short vegetation and non-flooded areas. The main components to calculate $G$ using the SEBAL algorithm are $T_{s}, N D V I$, and $R_{n}$, representing surface fluxes (including canopy and ground surface), while measured $G$ only accounts for ground surface. This is why the energy budget for tropical forests should be rewritten (Equation (19)) [92].

$$
R_{n}=H+L E+G+\Delta S+Q_{p}
$$

where $S$ corresponds to changes in total heat content within the canopy and $Q_{p}$ corresponds to the energy of photosynthesis. We also note that we used globally available equations in this study for estimating the energy balance components, however, more refined parameters could be adopted in a future work to improve algorithm performance and model structure.

\subsection{Uncertainties in the SEBAL Instantaneous and Daily ET Estimates}

Overall, the main SEBAL uncertainties are related to $H$ estimates and the selection of the hot and cold endmembers [35], yielding higher errors than the other surface energy balance components. However, we found accurate $H$ estimates using $g_{T s 1}-g_{T s 4}$ quantile groups, especially when compared to instantaneous measurements without energy balance closure. On the other hand, due to energy balance components being neglected or not computed for both eddy covariance measurements and SEBAL estimates, such as $\triangle S$ at diurnal time scale, SEBAL instantaneous $L E$ was overestimated, with MAE higher than $95.8 \mathrm{~W} \mathrm{~m}^{-2}$ for SEBAL-T and $111.6 \mathrm{~W} \mathrm{~m}^{-2}$ for SEBAL-M, suggesting significant differences on the instantaneous surface energy fluxes when compared to ground measurements. For instance, systematic biases in instrumentation and energy sources not considered in the process (storage in the air column or biomass) could give rise to uncertainties in the energy balance as well as losses of the turbulent fluxes at high or low frequencies [78]. Considering that SEBAL instantaneous $L E$ estimates were calculated as the residual of the energy balance, we also corrected measured $L E$ considering the energy balance closure at an instantaneous time scale. In this case, $L E$ was underestimated and MAE decreased significantly.

On the other hand, results indicate that the SEBAL slightly overestimated daily ET when compared to eddy covariance measurements, which is in accordance with other studies [51,55,61,95-97], with errors ranging between 0.3-0.4 $\mathrm{mm}_{\text {day }}{ }^{-1}$ when compared to measurements forced by energy balance closure techniques, and 0.6-0.8 $\mathrm{mm} \mathrm{day}^{-1}$ when compared to measurements without energy balance closure. A better performance of the SEBAL at a daily time scale is possibly related to the small fraction of $G$ and $\Delta S$ on a daily time scale [92,94], closely relying on the accurate estimates of $\Lambda$ and $R_{n_{24 h}}$. The use of the $\Lambda$ for upscaling instantaneous to daily surface fluxes based on remote sensing estimates is reliable, with assessments indicating a difference of less than $12 \%$ when compared to measured $\Lambda$, evidencing 
the agreement between SEBAL estimates and eddy covariance measurements [98], in close accordance with our findings.

\subsection{The SEBAL Sensitivity to Meteorological Inputs}

Overall, MERRA-2 provides more self-consistent meteorological data than its previous versions at large scale [68,99]. Although some validations of the recent MERRA-2 surface and atmospheric reanalysis have been published $[100,101]$, there is a lack of comprehensive assessment at regional scales.

Meteorological reanalysis uncertainties are mainly related to model structure and parameterization [102-104], since it is a theory-based calculation [105]. Therefore, the coarse spatial resolution can result in an increased likelihood of discrepancies between meteorological reanalysis and ground measurements, since they usually have limited spatial representativeness [102]. Meteorological reanalysis only provides large scale averages and does not represent the subgrid (misrepresenting local meteorological processes), therefore it suffers from biases especially over heterogeneous surfaces [106]. Thus, despite the moderate accuracy and biases at regional scales, as found at the JAV site, land data assimilation and reanalysis are becoming important sources of meteorological inputs for ET estimations [107].

Our results indicate that the use of ground measurements or global reanalysis data (MERRA-2) as meteorological inputs leads to low sensitivity on SEBAL accuracy to estimate surface energy and water fluxes. Only a few studies addressed the influence of meteorological inputs on SEBAL estimates, pointing out the small [108] to moderate sensitivity [109] of $u$. Considering $T_{a}$ and $R H$, used as inputs to compute downward longwave radiation and atmospheric transmissivity, respectively, the low sensitivity is related to the small fraction of these components in the surface energy balance during clear-sky days. On the other hand, Biggs et al. [17] reported a lower accuracy for the SEBAL driven by the use of MERRA-1 Land global climate data, especially for daily $R_{n}$, when compared to estimates driven by ground measurements. Indeed, errors in radiation $\left(R_{s}\right.$ or $\left.R_{n}\right)$ can cause large errors in $L E$ and ET estimations, e.g., Kich [109] demonstrated that an error of $10 \%$ in $R_{n}$ can cause an error up to $25 \%$ in $L E$.

Our findings confirm that temperature-based models rely on $T_{S}$ and $d T$, with a high sensitivity of $\Lambda$ and $R_{n_{24 h}}$ to upscaling instantaneous to daily fluxes [108,110,111], while vegetation-based models depend on vegetation conditions and reanalysis data from global climate grids, with a higher sensitivity to meteorological inputs $[17,112]$. Since our estimates of $\Lambda$ and $R_{n_{24 h}}$ yielded a high accuracy for both meteorological inputs, the most accurate daily ET estimates were for SEBAL-T and SEBAL-M when compared to vegetation-based model estimates in the Amazon biome [112,113].

\subsection{The SEBAL Sensitivity to Endmember Selection}

Endmember selection was assessed by using different quantiles of $T_{S}$ and NDVI. Our results clearly show that the selection of both hot and cold extreme endmembers result in high sensitivity to $H, L E$, and $E T$, playing a key role in the magnitude of surface fluxes estimates. Choragudi [108] and Long et al. [35] evaluated the sensitivity of the endmember selection, reporting a higher sensitivity for the hot endmember selection, where $T_{S}$ itself plays a secondary role in $L E$ and $E T$ estimations $[35,57]$. In contrast, changes in NDVI quantiles showed a lower sensitivity when compared to $T_{s}$, which is expected since the endmember selection is closely related to $d T$ [108].

An example of endmember candidates based on the nine quantile groups of $T_{S}$ and NDVI is presented in Figure 9 for the year 2004 DOY 200. Histograms of $T_{S}$ used for internal calibration are also presented. It is clear that the endmember selection based on $T_{s}$ and NDVI for different quantiles has a low sensitivity on the cold and a high sensitivity on the hot selection. For quantiles $g_{T_{s_{1}}}-g_{T_{s_{4}}}$, with changes in $T_{s}$ quantiles (keeping NDVI quantiles fixed), there is a decrease of $0.65 \mathrm{~K}$ for $T_{S}$ at the cold endmember and an increase of $2.4 \mathrm{~K}$ for $T_{S}$ at the hot endmember. On the other hand, for quantiles $g_{I V_{1}}-g_{I V_{4}}$, with changes in NDVI quantiles (keeping $T_{S}$ quantiles fixed), we found small changes in $T_{S}$ for both cold and hot endmembers (increase of $0.90 \mathrm{~K}$ and a decrease of $0.15 \mathrm{~K}$ for the hot and cold 
endmembers, respectively). Our findings are in agreement with Long et al. [35], indicating a higher sensitivity for $T_{S}$ rather than NDVI on $H$ and LE estimates.
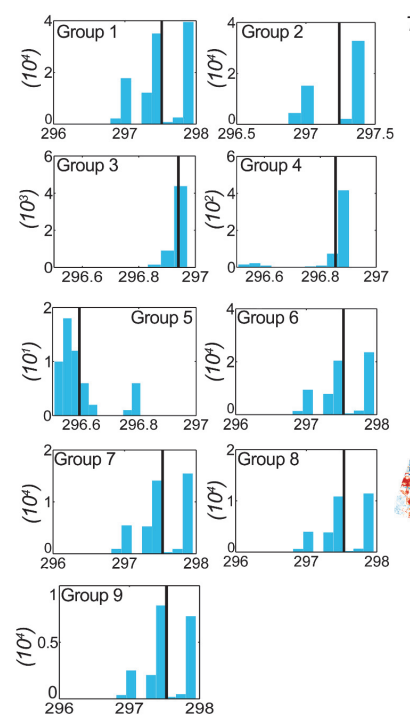
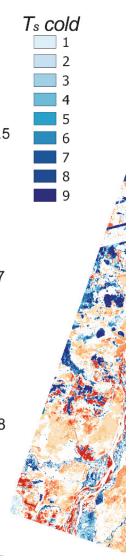
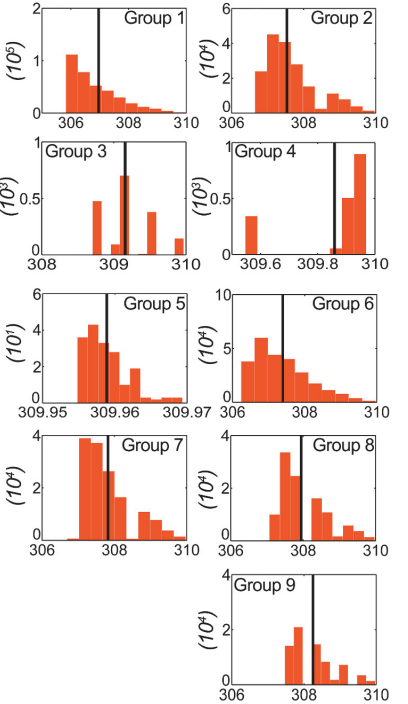

Figure 9. Example of endmember pixel selection for the year 2004 DOY 200 (center). $T_{S}$ cold (left) and $T_{S}$ hot (right) represent the hot and cold endmember candidates for each quantile group, respectively, while the black line indicates the selected endmember $T_{s}$. For each column chart, the $y$-axis represents pixel frequency while the $x$-axis represents $T_{s}$.

This higher sensitivity on the hot and dry endmember candidates was originally demonstrated by Bastiaanssen [53] and also observed by previous studies [58,114], where the endmembers play a key role in the SEBAL's internal calibration. The strong and accurate performance of the SEBAL and other surface energy balance models in heterogeneous areas was also demonstrated by other studies $[115,116]$ also considering wet and dry climate conditions $[61,95]$. The importance of the selection of the endmembers for $E T$ estimation was also highlighted $[35,57,114]$, however, our results indicate that the influence of pixel selection is more relevant than the meteorological data used to force the model, making reanalysis data such as from MERRA-2 useful for surface energy balance models.

\subsection{Spatial Assessment of Surface Energy and Water Fluxes}

Our study area is located in a transitional zone between forest and savanna in Central Brazil. Our estimates of energy partition (sensible and latent heat) for different land uses are in accordance with Restrepo-Coupe et al. [117], who showed that converted areas (forest to cropland and pasture) presented a different behavior with relative reductions in dry season $E T$, consistent with increasing water limitation due to loss of deep roots that can access soil water. They are also in agreement with Oliveira et al. [118] and Dias et al. [4], who conducted studies in the southwest (Ji-Paraná River basin) and southeast (Xingu River basin) Amazon on the conversion between forest vegetation and cropland and pasture, showing substantial changes on surface energy ( $H$ and $L E)$ and water $(E T)$ fluxes. Furthermore, changes in $\beta$ reflect alterations on surface energy fluxes partitioning between $H$ and $L E$. For instance, for forest areas we found a $\beta$ of 0.19 , while pasture areas presented a $\beta$ of 0.60 . In this context, land cover conversion leads to an increase of $\beta$, with an associated increase in $H$ and decrease in $L E$, causing an increase of $T_{a}$ and decrease in $E T$, mainly due to deforestation resulting in less vegetation being available to transpire water to the atmosphere [119].

\section{Conclusions}

Recent techniques of remote sensing and reanalysis data have improved our understanding of surface energy and water fluxes in the tropics. In this study, we presented an assessment of the SEBAL 
algorithm to estimate $H, L E$ and $E T$ driven by ground measurements and MERRA-2 reanalysis data. The comparison between SEBAL estimates against ground measurements yielded high accuracy for $R_{n}$, however, we found a high bias for $G$, suggesting a regional calibration. For $H$ and $L E$, eddy covariance measurements corrected with energy balance closure techniques yielded more accurate results when using both meteorological inputs in comparison to the non-closure measurements. Overall, SEBAL daily ET estimates presented higher accuracy than instantaneous fluxes. Furthermore, the automatic selection of endmembers was evaluated considering different $T_{S}$ and NDVI quantiles. Although daily ET estimates were less sensitive to the meteorological data, the endmember selection for SEBAL's internal calibration played a key role in estimations of surface fluxes. $T_{S}$ quantiles showed a higher sensitivity than NDVI quantiles, indicating its high influence on $H$ and $L E$ estimates on tropical biomes. Indeed, the strength of the SEBAL algorithm consists in the endmembers selection, while meteorological inputs have a lower impact on ET accuracy, providing consistent surface-energy partitioning at multiple land cover conditions independent of low accuracy input datasets.

The analyses reported here suggest that the SEBAL algorithm can capture surface fluxes for different land cover conditions at a regional scale within an acceptable accuracy, with significant potential for spatial and temporal monitoring based on MERRA-2 global reanalysis data and Landsat images in data-limited areas. In future research, long-term changes of surface fluxes across different land covers will be addressed, aiming to understand the impact of deforestation on land-atmosphere exchanges.

Supplementary Materials: The following are available online at http://www.mdpi.com/2072-4292/12/7/1108/s1, Table S1: Statistical metrics for SEBAL-T instantaneous surface fluxes estimates compared to ground, Table S2: Statistical metrics for SEBAL-M instantaneous surface fluxes estimates compared to ground measurements, Table S3: SEBAL-T statistics metrics for instantaneous $\Lambda$ and $E T_{24 h}$, Table S4: SEBAL-M statistics metrics for instantaneous $\Lambda$ and $E T_{24 h}$, Appendix A: List of abbreviations, Appendix B: List of variables.

Author Contributions: Conceptualization, A.L.R and A.S.F.; methodology, A.L.R. and A.S.F.; software, L.L, R.H.B.K. and E.d.M.K.; investigation, L.L., A.L.R. and A.S.F.; writing-original draft preparation, L.L., A.L.R., A.S.F.; writing-review and editing, C.M.U.N. and H.R.d.R.; supervision, A.L.R. and A.S.F.; project administration, A.L.R; funding acquisition, A.L.R., C.M.U.N. and H.R.d.R. All authors have read and agreed to the published version of the manuscript.

Funding: This research was financially supported by the Brazilian Water Agency (ANA) and by the Brazilian Ministry of Education through the Coordination for the Improvement of Higher Education Personnel (CAPES), under grants 88881.178687/2018-01 and 88887.363040/2019-00. It was also funded by the Brazilian National Council for Scientific Research (CNPq) under grant number 141161/2017-5. The support from the Daugherty Water for Food Global Institute is also greatly appreciated.

Acknowledgments: The authors would like to thank the LBA Project (Large-Scale Biosphere and Atmosphere Experiment in the Amazon) for data availability and to the Federal University of Rio Grande do Sul (UFRGS) for institutional support. We are also grateful to Wim Bastiaanssen for his extensive and insightful comments and suggestions that greatly contributed to this article.

Conflicts of Interest: The authors declare no conflict of interest.

\section{References}

1. Fisher, J.B.; Melton, F.; Middleton, E.; Hain, C.; Anderson, M.; Allen, R.; McCabe, M.F.; Hook, S.; Baldocchi, D.; Townsend, P.A.; et al. The future of evapotranspiration: Global requirements for ecosystem functioning, carbon and climate feedbacks, agricultural management, and water resources. Water Resour. Res. 2017, 53, 2618-2626. [CrossRef]

2. Panday, P.K.; Coe, M.T.; Macedo, M.N.; Lefebvre, P.; de Almeida Castanho, A.D. Deforestation offsets water balance changes due to climate variability in the Xingu River in eastern Amazonia. J. Hydrol. 2015, 523, 822-829. [CrossRef]

3. Pongratz, J.; Bounoua, L.; Defries, R.S.; Morton, D.C.; Anderson, L.O.; Mauser, W.; Klink, C.A. The impact of land cover change on surface energy and water balance in Mato Grosso, Brazil. Earth Interact. 2006, 10, 1-17. [CrossRef]

4. Dias, L.C.P.; Macedo, M.N.; Costa, M.H.; Coe, M.T.; Neill, C. Effects of land cover change on evapotranspiration and streamflow of small catchments in the Upper Xingu River Basin, Central Brazil. J. Hydrol. Reg. Stud. 2015, 4, 108-122. [CrossRef] 
5. Li, G.; Zhang, F.; Jing, Y.; Liu, Y.; Sun, G. Response of evapotranspiration to changes in land use and land cover and climate in China during 2001-2013. Sci. Total Environ. 2017, 256-265, 596-597. [CrossRef]

6. Aragão, L. Environmental science: The rainforest's water pump. Nature 2012, 489, 217-218. [CrossRef]

7. Spracklen, D.V.; Arnold, S.R.; Taylor, C.M. Observations of increased tropical rainfall preceded by air passage over forests. Nature 2012, 489, 282-285. [CrossRef]

8. Zemp, D.C.; Schleussner, C.-F.; Barbosa, H.M.J.; Hirota, M.; Montade, V.; Sampaio, G.; Staal, A.; Wang-Erlandsson, L.; Rammig, A. Self-amplified Amazon forest loss due to vegetation-atmosphere feedbacks. Nat. Commun. 2017, 8, 14681. [CrossRef]

9. Spera, S.A.; Galford, G.L.; Coe, M.T.; Macedo, M.N.; Mustard, J.F. Land-use change affects water recycling in Brazil's last agricultural frontier. Glob. Chang. Biol. 2016, 22, 3405-3413. [CrossRef]

10. Coe, M.; Latrubesse, E.; Ferreira, M.; Amsler, M. The effects of deforestation and climate variability on the streamflow of the Araguaia River, Brazil. Biogeochemistry 2011, 105, 119-131. [CrossRef]

11. da Silva, H.J.F.; Gonçalves, W.A.; Bezerra, B.G. Comparative analyzes and use of evapotranspiration obtained through remote sensing to identify deforested areas in the Amazon. Int. J. Appl. Earth Obs. Geoinf. 2019, 78, 163-174. [CrossRef]

12. Furlan, D.N. Land use and land cover effects on the water balance and surface energy balance on the Ji-pArana (RO) basin using multitemporal remote sensing data. Ph.D. Thesis, Universidade de São Paulo: Piracicaba, São Paulo, Brazil, 2013. (In Portuguese).

13. Lathuillière, M.J.; Dalmagro, H.J.; Black, T.A.; de Arruda, P.H.Z.; Hawthorne, I.; Couto, E.G.; Johnson, M.S. Rain-fed and irrigated cropland-atmosphere water fluxes and their implications for agricultural production in Southern Amazonia. Agric. For. Meteorol. 2018, 256-257, 407-419. [CrossRef]

14. Wright, J.S.; Fu, R.; Worden, J.R.; Chakraborty, S.; Clinton, N.E.; Risi, C.; Sun, Y.; Yin, L. Rainforest-initiated wet season onset over the southern Amazon. Proc. Natl. Acad. Sci. USA 2017, 114, 8481-8486. [CrossRef] [PubMed]

15. Costa, M.H.; Pires, G.F. Effects of Amazon and Central Brazil deforestation scenarios on the duration of the dry season in the arc of deforestation. Int. J. Climatol. 2009, 30, 1970-1979. [CrossRef]

16. McShane, R.R.; Driscoll, P.K.; Sando, R. A Review of Surface Energy Balance Models for Estimating Actual Evapotranspiration with Remote Sensing at High Spatiotemporal Resolution over Large Extents; Scientific Investigations Report 2017-5087; U.S. Geological Survey: Reston, VA, USA, 2017; 19p.

17. Biggs, T.W.; Marshall, M.; Messina, A. Mapping daily and seasonal evapotranspiration from irrigated crops using global climate grids and satellite imagery: Automation and methods comparison. Water Resour. Res. 2016, 52, 7311-7326. [CrossRef]

18. Kalma, J.D.; McVicar, T.R.; McCabe, M.F. Estimating land surface evaporation: A review of methods using remotely sensed surface temperature data. Surv. Geophys. 2008, 29, 421-469. [CrossRef]

19. Aubinet, M.; Vesala, T.; Papale, D. Eddy Covariance: A Practical Guide to Measurement and Data Analysis; Springer: Berlin/Heidelberg, Germany, 2012; ISBN 9789400723504.

20. Biggs, T.; Petropoulos, G.P.; Velpuri, N.M.; Marshall, M.; Glenn, E.P.; Nagler, P.L.; Messina, A. Remote Sensing of Actual Evapotranspiration from Cropland: Chapter 3. In Remote Ssensing Handbook, Vol. III: Remote Sensing of Water Resources, Disasters, and Urban Studies; Thenkabail, P.S., Ed.; CRC Press: Boca Raton, FL, USA, 2015.

21. Martens, B.; Miralles, D.G.; Lievens, H.; van der Schalie, R.; de Jeu, R.A.M.; Fernández-Prieto, D.; Beck, H.E.; Dorigo, W.A.; Verhoest, N.E.C. GLEAM v3: Satellite-based land evaporation and root-zone soil moisture. Geosci. Model Dev. 2017, 10, 1903-1925. [CrossRef]

22. Michel, D.; Jiménez, C.; Miralles, D.G.; Jung, M.; Hirschi, M.; Ershadi, A.; Martens, B.; McCabe, M.F.; Fisher, J.B.; $\mathrm{Mu}, \mathrm{Q}$; et al. The WACMOS-ET project - Part 1: Tower-scale evaluation of four remote-sensing-based evapotranspiration algorithms. Hydrol. Earth Syst. Sci. 2016, 20, 803-822. [CrossRef]

23. Miralles, D.G.; Jiménez, C.; Jung, M.; Michel, D.; Ershadi, A.; McCabe, M.F.; Hirschi, M.; Martens, B.; Dolman, A.J.; Fisher, J.B.; et al. The WACMOS-ET project - Part 2: Evaluation of global terrestrial evaporation data sets. Hydrol. Earth Syst. Sci. 2016, 20, 823-842. [CrossRef]

24. Mu, Q.; Zhao, M.; Running, S.W. Improvements to a MODIS global terrestrial evapotranspiration algorithm. Remote Sens. Environ. 2011, 115, 1781-1800. [CrossRef]

25. Fisher, J.B.; Tu, K.P.; Baldocchi, D.D. Global estimates of the land-atmosphere water flux based on monthly AVHRR and ISLSCP-II data, validated at 16 FLUXNET sites. Remote Sens. Environ. 2008, 112, 901-919. [CrossRef] 
26. Bastiaanssen, W.G.M.; Menenti, M.; Feddes, R.A.; Holtslag, A.A.M. A remote sensing surface energy balance algorithm for land (SEBAL): 1. Formulation. J. Hydrol. 1998, 212-213, 198-212. [CrossRef]

27. Allen, R.; Tasumi, M.; Trezza, R. Satellite-Based Energy Balance for Mapping Evapotranspiration With Internalized Calibration (METRIC) - Model. J. Irrig. Drain. Eng. 2007, 133. [CrossRef]

28. Anderson, M.; Kustas, W.P.; Norman, J.; Hain, C.; Mecikalski, J.R.; Schultz, L.; González-Dugo, M.; Cammalleri, C.; D'Urso, G.; Pimstein, A. Mapping daily evapotranspiration at field to continental scales using geostationary and polar orbiting satellite imagery. Hydrol. Earth Syst. Sci. 2011, 15, 223. [CrossRef]

29. Senay, G.B.; Bohms, S.; Singh, R.K.; Gowda, P.H.; Velpuri, N.M.; Alemu, H.; Verdin, J.P. Operational Evapotranspiration Mapping Using Remote Sensing and Weather Datasets: A New Parameterization for the SSEB Approach. JAWRA J. Am. Water Resour. Assoc. 2013, 49, 577-591. [CrossRef]

30. Su, B. The Surface Energy Balance System (SEBS) for Estimation of Turbulent Heat Fluxes. Hydrol. Earth Syst. Sci. 1988, 6. [CrossRef]

31. Jaafar, H.H.; Ahmad, F.A. Time series trends of Landsat-based ET using automated calibration in METRIC and SEBAL: The Bekaa Valley, Lebanon. Remote Sens. Environ. 2019. [CrossRef]

32. Senay, G.B.; Schauer, M.; Friedrichs, M.; Velpuri, N.M.; Singh, R.K. Satellite-based water use dynamics using historical Landsat data (1984-2014) in the southwestern United States. Remote Sens. Environ. 2017, 202, 98-112. [CrossRef]

33. Senay, B.G.; Schauer, M.; Velpuri, M.N.; Singh, K.R.; Kagone, S.; Friedrichs, M.; Litvak, E.M.; Douglas-Mankin, R.K. Long-Term (1986-2015) Crop Water Use Characterization over the Upper Rio Grande Basin of United States and Mexico Using Landsat-Based Evapotranspiration. Remote Sens. 2019, 11, 1587. [CrossRef]

34. Choragudi, V.N.R.K. Sensitivity analysis on mapping evapotranspiration at high resolution using internal calibration (METRIC). Civ. Eng. Theses Diss. Student Res. 2011, 78.

35. Long, D.; Singh, V.P.; Li, Z.-L. How sensitive is SEBAL to changes in input variables, domain size and satellite sensor? J. Geophys. Res. Atmos. 2011, 116. [CrossRef]

36. Morton, C.G.; Huntington, J.L.; Pohll, G.M.; Allen, R.G.; McGwire, K.C.; Bassett, S.D. Assessing Calibration Uncertainty and Automation for Estimating Evapotranspiration from Agricultural Areas Using METRIC. JAWRA J. Am. Water Resour. Assoc. 2013, 49, 549-562. [CrossRef]

37. Grosso, C.; Manoli, G.; Martello, M.; Chemin, Y.H.; Pons, D.; Teatini, P.; Piccoli, I.; Morari, F. Mapping Maize Evapotranspiration at Field Scale Using SEBAL: A Comparison with the FAO Method and Soil-Plant Model Simulations. Remote Sens. 2018, 10, 1452. [CrossRef]

38. Tang, R.; Li, Z.-L.; Chen, K.-S.; Jia, Y.; Li, C.; Sun, X. Spatial-scale effect on the SEBAL model for evapotranspiration estimation using remote sensing data. Agric. For. Meteorol. 2013, 174-175, $28-42$. [CrossRef]

39. Sun, Z.; Wei, B.; Su, W.; Shen, W.; Wang, C.; You, D.; Liu, Z. Evapotranspiration estimation based on the SEBAL model in the Nansi Lake Wetland of China. Math. Comput. Model. 2011, 54, 1086-1092. [CrossRef]

40. de Teixeira, A.H.C.; Bastiaanssen, W.G.M.; Ahmad, M.D.; Bos, M.G. Reviewing SEBAL input parameters for assessing evapotranspiration and water productivity for the Low-Middle São Francisco River basin, Brazil. Agric. For. Meteorol. 2009, 149, 462-476. [CrossRef]

41. Al Zayed, I.S.; Elagib, N.A.; Ribbe, L.; Heinrich, J. Satellite-based evapotranspiration over Gezira Irrigation Scheme, Sudan: A comparative study. Agric. Water Manag. 2016, 177, 66-76. [CrossRef]

42. Yang, Y.; Shang, S.; Jiang, L. Remote sensing temporal and spatial patterns of evapotranspiration and the responses to water management in a large irrigation district of North China. Agric. For. Meteorol. 2012, 164, 112-122. [CrossRef]

43. Allen, R.; Kilic, A.; Trezza, R.; Hendrickx, J.; Bastiaanssen, W.G.M.; Kjaersgaard, J. Satellite-based ET estimation in agriculture using SEBAL and METRIC. Hydrol. Process. 2011, 25, 4011-4027. [CrossRef]

44. Sando, R.; Caldwell, R.R.; Blasch, K. Using Remote Sensing to Characterize and Compare Evapotranspiration from Different Irrigation Regimes in the Smith River Watershed of Central Montana. Irrig. Drain. Syst. Eng. 2017, 6, 1-10. [CrossRef]

45. Li, S.; Zhao, W. Satellite-based actual evapotranspiration estimation in the middle reach of the Heihe River Basin using the SEBAL method. Hydrol. Process. 2010, 24, 3337-3344. [CrossRef]

46. Bandara, K.M.P. Monitoring irrigation performance in Sri Lanka with high-frequency satellite measurements during the dry season. Agric. Water Manag. 2003, 58, 159-170. [CrossRef] 
47. Bastiaanssen, W.G.M.; Ali, S. A new crop yield forecasting model based on satellite measurements applied across the Indus Basin, Pakistan. Agric. Ecosyst. Environ. 2003, 94, 321-340. [CrossRef]

48. da Silva, B.B.; Wilcox, B.P.; da Silva, V.D.P.R.; Montenegro, S.M.G.L.; de Oliveira, L.M.M. Changes to the energy budget and evapotranspiration following conversion of tropical savannas to agricultural lands in São Paulo State, Brazil. Ecohydrology 2014, 8, 1272-1283. [CrossRef]

49. de Oliveira Costa, J.; Coelho, R.; Wolff, W.; José, J.; Folegatti, M.; Ferraz, S. Spatial variability of coffee plant water consumption based on the SEBAL algorithm. Sci. Agric. 2019, 76, 93-101. [CrossRef]

50. Kiptala, J.K.; Mohamed, Y.; Mul, M.L.; der Zaag, P. Mapping evapotranspiration trends using MODIS and SEBAL model in a data scarce and heterogeneous landscape in Eastern Africa. Water Resour. Res. 2013, 49, 8495-8510. [CrossRef]

51. Numata, I.; Khand, K.; Kjaersgaard, J.; Cochrane, M.A.; Silva, S.S. Evaluation of Landsat-Based METRIC Modeling to Provide High-Spatial Resolution Evapotranspiration Estimates for Amazonian Forests. Remote Sens. 2017, 9, 46. [CrossRef]

52. Ruhoff, A.; Paz, A.; Collischonn, W.; Aragão, L.; Rocha, H.R.; Malhi, Y.S. A MODIS-Based Energy Balance to Estimate Evapotranspiration for Clear-Sky Days in Brazilian Tropical Savannas. Remote Sens. 2012, 4, 703-725. [CrossRef]

53. Bastiaanssen, W.G.M. Regionalization of Surface Flux Densities and Moisture Indicators in Composite Terrain: A Remote Sensing Approach under Clear Skies in Mediterranean Climates. SC-DLO: Wageningen, Gelderland, The Netherlands, 1995.

54. Allen, R.G.; Burnett, B.; Kramber, W.; Huntington, J.; Kjaersgaard, J.; Kilic, A.; Kelly, C.; Trezza, R. Automated Calibration of the METRIC-Landsat Evapotranspiration Process. JAWRA J. Am. Water Resour. Assoc. 2013, 49, 563-576. [CrossRef]

55. Bhattarai, N.; Quackenbush, L.J.; Im, J.; Shaw, S.B. A new optimized algorithm for automating endmember pixel selection in the SEBAL and METRIC models. Remote Sens. Environ. 2017, 196, 178-192. [CrossRef]

56. Silva, A.M.; da Silva, R.M.; Santos, C.A.G. Automated surface energy balance algorithm for land (ASEBAL) based on automating endmember pixel selection for evapotranspiration calculation in MODIS orbital images. Int. J. Appl. Earth Obs. Geoinf. 2019, 79, 1-11. [CrossRef]

57. Feng, L. Sensitivity Analysis of Hot/Cold Pixel Selection in SEBAL Model for ET Estimation. Ph.D. Thesis, Virginia Polytechnic Institute and State University, Blacksburg, VA, USA, 2015.

58. Long, D.; Singh, V.P. Assessing the impact of end-member selection on the accuracy of satellite-based spatial variability models for actual evapotranspiration estimation. Water Resour. Res. 2013, 49, 2601-2618. [CrossRef]

59. Long, D.; Singh, V.P. A modified surface energy balance algorithm for land (M-SEBAL) based on a trapezoidal framework. Water Resour. Res. 2012, 48. [CrossRef]

60. Lee, Y.; Kim, S. The Modified SEBAL for Mapping Daily Spatial Evapotranspiration of South Korea Using Three Flux Towers and Terra MODIS Data. Remote Sens. 2016, 8, 983. [CrossRef]

61. Bhattarai, N.; Mallick, K.; Stuart, J.; Vishwakarma, B.D.; Niraula, R.; Sen, S.; Jain, M. An automated multi-model evapotranspiration mapping framework using remotely sensed and reanalysis data. Remote Sens. Environ. 2019, 229, 69-92. [CrossRef]

62. Baik, J.; Liaqat, U.; Choi, M. Assessment of satellite- and reanalysis-based evapotranspiration products with two blending approaches over the complex landscapes and climates of Australia. Agric. For. Meteorol. 2018, 263, 388-398. [CrossRef]

63. Yuan, W.; Liu, S.; Yu, G.; Bonnefond, J.-M.; Chen, J.; Davis, K.; Desai, A.R.; Goldstein, A.H.; Gianelle, D.; Rossi, F.; et al. Global estimates of evapotranspiration and gross primary production based on MODIS and global meteorology data. Remote Sens. Environ. 2010, 114, 1416-1431. [CrossRef]

64. Ishak, A.M.; Bray, M.; Remesan, R.; Han, D. Estimating reference evapotranspiration using numerical weather modelling. Hydrol. Process. 2010, 24, 3490-3509. [CrossRef]

65. Costa, M.H.; Foley, J.A. Trends in the hydrologic cycle of the Amazon basin. J. Geophys. Res. Atmos. 1999, 104, 14189-14198. [CrossRef]

66. Kalnay, E.; Kanamitsu, M.; Kistler, R.; Collins, W.; Deaven, D.; Gandin, L.; Iredell, M.; Saha, S.; White, G.; Woollen, J.; et al. The NCEP/NCAR 40-year reanalysis project. Bull. Am. Meteorol. Soc. 1996, 77, 437-471. [CrossRef] 
67. Dee, D.P.; Uppala, S.M.; Simmons, A.J.; Berrisford, P.; Poli, P.; Kobayashi, S.; Andrae, U.; Balmaseda, M.A.; Balsamo, G.; Bauer, P.; et al. The ERA-Interim reanalysis: Configuration and performance of the data assimilation system. Q. J. R. Meteorol. Soc. 2011. [CrossRef]

68. Gelaro, R.; McCarty, W.; Suárez, M.J.; Todling, R.; Molod, A.; Takacs, L.; Randles, C.A.; Darmenov, A.; Bosilovich, M.G.; Reichle, R.; et al. The Modern-Era Retrospective Analysis for Research and Applications, Version 2 (MERRA-2). J. Clim. 2017, 30, 5419-5454. [CrossRef] [PubMed]

69. Borma, L.S.; da Rocha, H.R.; Cabral, O.M.; von Randow, C.; Collicchio, E.; Kurzatkowski, D.; Brugger, P.J.; Freitas, H.; Tannus, R.; Oliveira, L.; et al. Atmosphere and hydrological controls of the evapotranspiration over a floodplain forest in the Bananal Island region, Amazonia. J. Geophys. Res. 2009, 114, G01003. [CrossRef]

70. Rocha, H.; Manzi, A.; Cabral, O.D.; Miller, S.L.; Goulden, M.; Saleska, S.; Restrepo-Coupe, N.; Wofsy, S.; Borma, L.; Artaxo, P.; et al. Patterns of water and heat flux across a biome gradient from tropical forest to savanna in Brazil. J. Geophys. Res. 2009, 114. [CrossRef]

71. Tollefson, J. Deforestation ticks up in Brazil's savannah. Nature 2018, 12. [CrossRef]

72. Alvares, C.A.; Stape, J.L.; Sentelhas, P.C.; de Moraes, G.; Leonardo, J.; Sparovek, G. Köppen's climate classification map for Brazil. Meteorol. Zeitschrift 2013, 22, 711-728. [CrossRef]

73. Oliveira, L.D.S. Surface and atmospheric fluxes over the Bananal Insland ecotone. Ph.D. Thesis, Universidade de São Paulo: São Paulo, São Paulo, Brazil, 2006. (In Portuguese).

74. de Gonçalves, L.S.; Borak, J.; Costa, M.; Saleska, S.; Baker, I.; Restrepo-Coupe, N.; Muza, M.; Poulter, B.; Verbeeck, H.B.; Fisher, J.; et al. Overview of the Large-Scale Biosphere-Atmosphere Experiment in Amazonia Data Model Intercomparison Project (LBA-DMIP). Agric. For. Meteorol. 2013, 182-183, 111-127.

75. Keller, M.; Dias, M.; Nepstad, D.; Andreae, M. The Large-Scale Biosphere-Atmosphere Experiment in Amazonia: Analyzing Regional Land Use Change Effects. Ecosyst. Land Use Chang. 2004, 153, 321-334.

76. Christoffersen, B.O.; Restrepo-Coupe, N.; Arain, M.A.; Baker, I.T.; Cestaro, B.P.; Ciais, P.; Fisher, J.B.; Galbraith, D.; Guan, X.; Gulden, L.; et al. Mechanisms of water supply and vegetation demand govern the seasonality and magnitude of evapotranspiration in Amazonia and Cerrado. Agric. For. Meteorol. 2014, 191, 33-50. [CrossRef]

77. Saleska, S.R.; Da Rocha, H.R.; Huete, A.R.; Nobre, A.D.; Artaxo, P.E.; Shimabukuro, Y.E. LBA-ECO CD-32 Flux Tower Network Data Compilation, Brazilian Amazon: 1999-2006. Available online: http: //daac.ornl.gov/LBA/guides/CD32_Brazil_Flux_Network.html (accessed on 2 February 2020).

78. Wilson, K.; Goldstein, A.; Falge, E.; Aubinet, M.; Baldocchi, D.; Berbigier, P.; Bernhofer, C.; Ceulemans, R.; Dolman, H.; Field, C.; et al. Energy balance closure at FLUXNET sites. Agric. For. Meteorol. 2002, 113, $223-243$. [CrossRef]

79. Twine, T.E.; Kustas, W.P.; Norman, J.M.; Cook, D.R.; Houser, P.R.; Meyers, T.P.; Prueger, J.H.; Starks, P.J.; Wesely, M.L. Correcting eddy-covariance flux underestimates over a grassland. Agric. For. Meteorol. 2000, 103, 279-300. [CrossRef]

80. Jung, M.; Reichstein, M.; Ciais, P.; Seneviratne, S.I.; Sheffield, J.; Goulden, M.L.; Bonan, G.; Cescatti, A.; Chen, J.; de Jeu, R.; et al. Recent decline in the global land evapotranspiration trend due to limited moisture supply. Nature 2010, 467, 951-954. [CrossRef] [PubMed]

81. Wohlfahrt, G.; Widmoser, P. Can an energy balance model provide additional constraints on how to close the energy imbalance? Agric. For. Meteorol. 2013, 169, 85-91. [CrossRef]

82. Shuttleworth, W.J. Terrestrial Hydrometeorology, 1 st ed.; John Wiley \& Sons, Ltd.: Chichester, UK, 2012; ISBN 9781119951933.

83. Bastiaanssen, W.G.M. SEBAL-based sensible and latent heat fluxes in the irrigated Gediz Basin, Turkey. J. Hydrol. 2000, 229, 87-100. [CrossRef]

84. Tasumi, M.; Allen, R.G.; Trezza, R. At-Surface Reflectance and Albedo from Satellite for Operational Calculation of Land Surface Energy Balance. J. Hydrol. Eng. 2008, 13, 51-63. [CrossRef]

85. Dhungel, S.; Barber, M. Remote sensing Estimating Calibration Variability in Evapotranspiration Derived from a Satellite-Based Energy Balance Model. Remote Sens. 2018, 10, 1695. [CrossRef]

86. de Bruin, H.A. From penman to makkink. Evaporation Weather 1987, 39, 5-31.

87. Lasdon, L.L.; Fox, R.W.; Ratner, M. Nonlinear Optimization Using the Generalized Reduced Gradient Method. Rev. Française d'Automatique, Informatique, Rech. Opérationnelle. Série Verte 1973, 8, 63.

88. MapBiomas Project MapBiomas - Collection 3.1 of Brazilian Land Cover \& Use Map Series. Available online: http://mapbiomas.org/ (accessed on 1 March 2019). 
89. Fearnside, P. Deforestation of the Brazilian Amazon. In Oxford Research Encyclopedia of Environmental Science; Oxford University Press: Oxford, UK, 2017.

90. Noojipady, P.; Morton, C.D.; Macedo, N.M.; Victoria, C.D.; Huang, C.; Gibbs, K.H.; Bolfe, L.E. Forest carbon emissions from cropland expansion in the Brazilian Cerrado biome. Environ. Res. Lett. 2017, 12, 25004. [CrossRef]

91. de Oliveira, G.; Brunsell, N.; Moraes, E.; Bertani, G.; dos Santos, T.; Shimabukuro, Y.; Aragão, L. Use of MODIS Sensor Images Combined with Reanalysis Products to Retrieve Net Radiation in Amazonia. Sensors 2016, 16, 956. [CrossRef]

92. Moore, C.J.; Fisch, G. Estimating heat storage in Amazonian tropical forest. Agric. For. Meteorol. 1986, 38, 147-168. [CrossRef]

93. da Silva, V.D.P.R.; Almeida, R.S.R.; Dantas, V.D.A.; da Costa, A.C.L.; Singh, V.P. Sensible and Latent Heat Storage Fluxes within the Canopy Air-Space in the Amazon Rainforest. For. Res. 2012, 1, 1-5. [CrossRef]

94. Malhi, Y.; Pegoraro, E.; Nobre, A.D.; Pereira, M.G.P.; Grace, J.; Culf, A.D.; Clement, R. Energy and water dynamics of a central Amazonian rain forest. J. Geophys. Res. 2002, 107, 8061. [CrossRef]

95. Bhattarai, N.; Shaw, S.B.; Quackenbush, L.J.; Im, J.; Niraula, R. Evaluating five remote sensing based single-source surface energy balance models for estimating daily evapotranspiration in a humid subtropical climate. Int. J. Appl. Earth Obs. Geoinf. 2016, 49, 75-86. [CrossRef]

96. Khand, K.; Numata, I.; Kjaersgaard, J.; Vourlitis, G. Dry Season Evapotranspiration Dynamics over Human-Impacted Landscapes in the Southern Amazon Using the Landsat-Based METRIC Model. Remote Sens. 2017, 9, 706. [CrossRef]

97. Wagle, P.; Bhattarai, N.; Gowda, P.H.; Kakani, V.G. Performance of five surface energy balance models for estimating daily evapotranspiration in high biomass sorghum. ISPRS J. Photogramm. Remote Sens. 2017, 128, 192-203. [CrossRef]

98. dos Santos, C.A.C.; da Silva, B.B.; Rao, T.V.R. Analysis of the evaporative fraction using eddy covariance and remote sensing techniques. Rev. Bras. Meteorol. 2010, 25, 427-436. [CrossRef]

99. Reichle, R.H.; Liu, Q.; Koster, R.D.; Draper, C.S.; Mahanama, S.P.P.; Partyka, G.S. Land Surface Precipitation in MERRA-2. J. Clim. 2017, 30, 1643-1664. [CrossRef]

100. Jia, A.; Liang, S.; Jiang, B.; Zhang, X.; Wang, G. Comprehensive Assessment of Global Surface Net Radiation Products and Uncertainty Analysis. J. Geophys. Res. Atmos. 2018, 123, 1970-1989. [CrossRef]

101. Reichle, R.H.; Draper, C.S.; Liu, Q.; Girotto, M.; Mahanama, S.P.P.; Koster, R.D.; De Lannoy, G.J.M. Assessment of MERRA-2 Land Surface Hydrology Estimates. J. Clim. 2017, 30, 2937-2960. [CrossRef]

102. Draper, C.S.; Reichle, R.H.; Koster, R.D. Assessment of MERRA-2 Land Surface Energy Flux Estimates. J. Clim. 2018, 31, 671-691. [CrossRef]

103. Schlosser, C.A.; Gao, X. Assessing Evapotranspiration Estimates from the Second Global Soil Wetness Project (GSWP-2) Simulations. J. Hydrometeorol. 2010, 11, 880-897. [CrossRef]

104. Mueller, B.; Hirschi, M.; Jimenez, C.; Ciais, P.; Dirmeyer, P.A.; Dolman, A.J.; Fisher, J.B.; Jung, M.; Ludwig, F.; Maignan, F.; et al. Benchmark products for land evapotranspiration: LandFlux-EVAL multi-data set synthesis. Hydrol. Earth Syst. Sci. 2013, 17, 3707-3720. [CrossRef]

105. Parker, W.S. Reanalyses and Observations: What's the Difference? Bull. Am. Meteorol. Soc. 2016, 97, 1565-1572. [CrossRef]

106. Rasp, S.; Pritchard, M.S.; Gentine, P. Deep learning to represent subgrid processes in climate models. Proc. Natl. Acad. Sci. USA 2018, 115, 9684-9689. [CrossRef]

107. Lewis, C.S.; Geli, H.M.E.; Neale, C.M.U. Comparison of the NLDAS Weather Forcing Model to Agrometeorological Measurements in the western United States. J. Hydrol. 2014, 510, 385-392. [CrossRef]

108. Choragudi, V. Sensitivity Analysis on Mapping EvapoTranspiration at High Resolution Using Internal Calibration (METRIC). 2011. Available online: https:/digitalcommons.unl.edu/civilengdiss/35/ (accessed on 3 March 2020).

109. Kich, E. Automated calibration of the Surface Energy Balance Algorithm for Land (SEBAL) to estimate evapotranspiration. Master Dissertation, Universidade Federal do Rio Grande do Sul, Porto Alegre, Rio Grande do Sul, Brazil, 2018. (In Portuguese).

110. Wang, J.; Sammis, T.W.; Gutschick, V.P.; Gebremichael, M.; Miller, D.R. Miller Sensitivity Analysis of the Surface Energy Balance Algorithm for Land (SEBAL). Trans. ASABE 2009, 52, 801-811. [CrossRef] 
111. Timmermans, W.J.; Kustas, W.P.; Anderson, M.C.; French, A.N. An intercomparison of the Surface Energy Balance Algorithm for Land (SEBAL) and the Two-Source Energy Balance (TSEB) modeling schemes. Remote Sens. Environ. 2007, 108, 369-384. [CrossRef]

112. Gomis-Cebolla, J.; Jimenez, J.C.; Sobrino, J.A.; Corbari, C.; Mancini, M. Intercomparison of remote-sensing based evapotranspiration algorithms over amazonian forests. Int. J. Appl. Earth Obs. Geoinf. 2019, 80, $280-294$. [CrossRef]

113. da Paca, V.H.M.; Espinoza-Dávalos, G.E.; Hessels, T.M.; Moreira, D.M.; Comair, G.F.; Bastiaanssen, W.G.M. The spatial variability of actual evapotranspiration across the Amazon River Basin based on remote sensing products validated with flux towers. Ecol. Process. 2019, 8, 6. [CrossRef]

114. Mokhtari, M.H.; Ahmad, B.; Hoveidi, H.; Busu, I. Sensitivity analysis of METRIC-based evapotranspiration algorithm. Int. J. Environ. Res. 2013, 7, 407-422.

115. Santos, C.A.G.; da Silva, R.M.; Silva, A.M.; Brasil Neto, R.M. Estimation of evapotranspiration for different land covers in a Brazilian semi-arid region: A case study of the Brígida River basin, Brazil. J. South Am. Earth Sci. 2017, 74, 54-66. [CrossRef]

116. Chirouze, J.; Boulet, G.; Jarlan, L.; Fieuzal, R.; Rodriguez, J.C.; Ezzahar, J.; Er-Raki, S.; Bigeard, G.; Merlin, O.; Garatuza-Payan, J.; et al. Intercomparison of four remote-sensing-based energy balance methods to retrieve surface evapotranspiration and water stress of irrigated fields in semi-arid climate. Hydrol. Earth Syst. Sci. 2014, 18, 1165-1188. [CrossRef]

117. Restrepo-Coupe, N.; Rocha, H.; Hutyra, L.; de Araújo, A.; Borma, L.; Christoffersen, B.; Cabral, O.; Camargo, P.L.; Cardoso, F.; da Costa, A.; et al. What drives the seasonality of photosynthesis across the Amazon basin? A cross-site analysis of eddy flux tower measurements from the Brasil flux network. Agric. For. Meteorol. 2013, 182-183, 128-144. [CrossRef]

118. Oliveira, G.; Brunsell, N.A.; Moraes, E.C.; Shimabukuro, Y.E.; Santos, T.V.; Randow, C.; Aguiar, R.G.; Aragao, L.E.O.C. Effects of land-cover changes on the partitioning of surface energy and water fluxes in Amazonia using high-resolution satellite imagery. Ecohydrology 2019, 12, e2126. [CrossRef]

119. Davidson, E.A.; de Araújo, A.C.; Artaxo, P.; Balch, J.K.; Brown, I.F.; Bustamante, M.M.C.; Coe, M.T.; DeFries, R.S.; Keller, M.; Longo, M.; et al. Erratum: Corrigendum: The Amazon basin in transition. Nature 2012, 483, 232. [CrossRef] 